REGULAR ARTICLE

\title{
INDIVIDUAL OR GROUP-BASED APPROACH TO THE ASSESSMENT OF PRESCHOOL CHILDREN: A COMPARISON USING THE INTERGROWTH-21 ${ }^{\text {ST }}$ NEURODEVELOPMENT ASSESSMENT (INTER-NDA)
}

\author{
JOHANNA SLIM1, JOSE VILLAR²,3, GABRIELA GUERRERO VARELA, FRANCISCA HERNANDEZ \\ CASTILLO', MARIA DE LA LUZ LOZADA GUZMÁN, ANGÉLICA BUCHÁN DURÁNi, \\ LEILA CHEIKH ISMAIL4,2, SANDY SAVINI², PILAR VAZQUEZ ARANGO², ALAN STEIN5, \\ STEPHEN KENNEDY'2,3, MICHELLE FERNANDES6,2*
}

${ }^{1}$ Programa de Educacion Inicial, Fundación Carlos Slim, Mexico City, Mexico

${ }^{2}$ Nuffield Department of Obstetrics and Gynaecology, John Radcliffe Hospital, University of Oxford, Oxford, United Kingdom

3Oxford Maternal and Perinatal Health Institute, Green Templeton College, University of Oxford, Oxford, United Kingdom

${ }^{4}$ Clinical Nutrition and Dietetics Department, College of Health Sciences, University of Sharjah, Sharjah, UAE

5Department of Psychiatry, Warneford Hospital, University of Oxford, Oxford, United Kingdom

${ }^{6}$ Department of Paediatrics, Southampton Children's Hospital, University of Southampton, Southampton, United Kingdom

\section{INTRODUCTION}

It has been estimated that 250 million preschool children in low-and middle-income countries are at risk of not achieving their developmental potential [1]. The first step in addressing this issue is the accurate identification of children at risk of developmental disturbances. Most assessments of early child development (ECD) are complex and targeted at the individual, including the Bayley Scales of Infant Development [2], the Griffiths Scales of Child Development [3] and the Denver Development Screening Test [4]. There is limited information on 'small groupbased' approaches to ECD measurement as a strategy to increase coverage and it is not known whether assessing children in small groups is feasible and comparable to individual assessment.

Concerns about the reliability of developmental scores obtained through group-based ECD assessments arise because of inter-child interference, disruption and mimicry. Scoring multiple children simultaneously in an unbiased format can be challenging. It may be possible, however, to implement ECD assessments in small groups in settings such as preschools where the children are already familiar with the assessor, the environment and other participants.

The INTERGROWTH-21 ${ }^{\text {st }}$ Neurodevelopment Assessment (INTER-NDA) is a 53-item ECD assessment developed by The International Fetal and Newborn Growth Consortium for the $21^{\text {st }}$ Century (INTERGROWTH-21 ${ }^{\text {st }}$ ) Project $[5,6]$. The INTER-NDA measures cognition, language (expressive and receptive), motor skills (fine and gross), behavior (positive, negative and global), attention and socio-emotional reactivity in 22 to 26 months old children. It consists of directly administered, concurrently observed and caregiver-reported items, scored on a 5-point scale. It was developed for, and implemented in, the INTERGROWTH-21 ${ }^{\text {st }}$ Project on an individual child basis.

During the piloting of the INTER-NDA in preschools in Mexico City, it was suggested that a small group strategy might be more appropriate for large-scale dissemination through the educational system and for achieving large coverage as a first level-screening program. We therefore designed this study, in the context of the INTERGROWTH-21 ${ }^{\text {st }}$ Project global dissemination program, with the aim of comparing INTER-NDA scores obtained from the individual and group approaches after controlling for age, sex, nutritional status and location of the school.

\section{MATERIALS AND METHODS}

\section{Location}

The study was carried out between March and June 2015 in four Centros de Cuidado y Atención Infantil of the Mexican Sistema Nacional para el Desarrollo Integral de la Familia (DIF) (Casita de Susi, Yoltzin, Mundo de Andi

\footnotetext{
Received 27 March 2018; Accepted 21 May 2018

*Corresponding Author

Michelle Fernandes

Department of Paediatrics, Southampton Children's Hospital, University of Southampton, Southampton, United Kingdom

Email: m.c.fernandes@soton.ac.uk

OThis article is open access and licensed under the terms of the Creative Commons Attribution License (http://creativecommons.org/licenses/by/4.o/) which permits unrestricted, use, distribution and reproduction in any medium, or format for any purpose, even commercially provided the work is properly cited. Attribution - You must give appropriate credit, provide a link to the license, and indicate if changes were made.
} 
and CBI). They are located in Mexico City catering for children of lower-middle socio-economic status who participated in the study. All the teachers were staff of the Casa Telmex-Centro Histórico, qualified in preschool education through a degree from the institution conducting this study, the Programama de Educacion Inicial, Fundacion Carlos Slim, a private educational service committed to promoting the preschool education of Mexican children.

\section{Recruitment}

Children were recruited into the study if they: (i) were aged 22 to 26 months; (ii) were healthy at the time of the assessment; (iii) had been enrolled in the preschool for a minimum of 6 months (to ensure they were familiar to their peers and teachers); (iv) were not previously exposed to neurodevelopmental testing, and (v) were native in Mexican Spanish.

\section{Methods}

The INTER-NDA's scoring system is an objective report of the child's performance rather than subjective judgment by the assessor. The assessment was designed for use in international settings with emphasis on avoiding the use of culture-specific items. It has good inter-rater and testretest reliability $(\mathrm{k}=0.70,95 \% \mathrm{CI} 0.47-0.88 ; \mathrm{k}=0.79,95 \% \mathrm{CI}$ 0.48-0.96)[5]. The administration and scoring of the INTER-NDA follow a standardized protocol (www. intergrowth21. org. uk). The INTER-NDA takes 15-20 min to complete in its original individual format.

The individual assessment protocol of the INTER-NDA was modified (by MF) to ensure that groups of three children could be assessed simultaneously. This involved INTER-NDA items being presented one at a time to each child, ensuring that each child was presented with different items during each presentation cycle. The sequence of presentation of cognitive, language and fine motor items (items 1-21 of the INTER-NDA) for each of the three children in a group was designed so that (i) all items were eventually presented to all the children and (ii) once an item in a cycle was presented to any one child, it would not be presented to the other children until at least two cycles comprising different items were completed. The rationale was to reduce the ability of the second child to remember how to solve a particular task after witnessing the first child's performance. Care was taken to ensure that items, which follow on from each other (for example, the puzzle board and reverse puzzle board, and the naming and matching of colored cubes) were not affected. Children were encouraged to complete gross motor items together, before the conclusion of the assessment. Caregiver reported and behavior related items were completed by the teachers, after the cognitive, language and motor items were administered.

The INTER-NDA was translated into Mexican Spanish following a standardized translation and back-translation protocol (by SS, GGV and FHC)[7]. Eight preschool teachers (two from each participating preschool) were trained and standardized in the INTER-NDA during a 3-day training session (by MF and SS) that included both individual and group assessments. Teachers were supported by the technical staff responsible for developmental evaluation of children of the Sistema Nacional para el Desarrollo Integral de la Familia (DIF) of Mexico.

The weight, length and head circumference of the children were measured according to anthropometric protocols of the INTERGROWTH-21 ${ }^{\text {st }}$ Project[8]. Weight was measured using a portable electronic scale (Seca) with taring capability and calibrated to $0.1 \mathrm{~kg}$. Length was measured in $\mathrm{cm}$ to the last completed $\mathrm{mm}$ using the Harpenden Portable Stadiometer. The equipment was calibrated before measuring each child. A 0.7-cm-wide, flat paper tape (range, $0-200 \mathrm{~cm}$, calibrated to $1 \mathrm{~mm}$ ) was used to measure head circumference. Two sets of measurements for weight, length and head circumference were taken and recorded by two trained preschool teachers. The preschool teachers were standardized and trained by the INTERGROWTH-21 ${ }^{\text {st }}$ Project's lead anthropometrist (LCI).

Forty-two children were selected from the four preschools and divided into six groups. Each group consisted of two girls and a boy, or two boys and a girl. All assessments were carried out in a preschool classroom. In the first part of the assessment, the teacher administered the INTER-NDA according to the group assessment protocol described above to a group of three children seated at a table. A second teacher was seated non-intrusively in the room, and recorded the performance of each child on a score sheet.

In the second part of the comparison, the second teacher assessed children individually, without other children in the room. At the end of the final assessment, the child's weight, length and head circumference were recorded.

The individual and group assessments were conducted a day apart. For the first three groups of children, the group assessment was conducted on day 1 and the individual assessment on day 2; this order was reversed for the remaining three groups of children. All assessments were conducted in Mexican Spanish. The results were not used for any clinical or academic evaluation of children and were analyzed anonymously without any link or report to the school record of the children.

The authorities with legal responsibility for; and the head of the institution of; the Centros de Cuidado $y$ Atención Infantil of the Sistema Nacional para el Desarrollo Integral de la Familia, Mexico City, Mexico, reviewed the project and provided written approval for its conduct. The investigators then had a detailed discussion with the teaching staff and parents/guardians. The teachers themselves obtained written informed consent from the parents/guardians of all participating children.

\section{Statistical analysis}

Descriptive statistics for each INTER-NDA domain, i.e. cognition, gross motor, fine motor, expressive language, receptive language, positive behavior, negative behavior, global behavior, attention and socio-emotional reactivity were calculated for each child for the group and individual assessments. To determine whether there was consistency between scores obtained from group and individual assessments, continuous correlations were calculated for each INTER-NDA domain. To determine whether significant differences in INTER-NDA domain scores existed between individual and group assessments, we carried out paired t tests. Due to the similarity in scores for some INTER-NDA domains, we did not use intra-class correlation coefficients between group and individual scores, as they are known to function best in situations of high heterogeneity in the data [9].

To determine agreement between INTER-NDA domain scores obtained from group and individual assessments a 
Bland-Altman analysis was carried out using the recommended strategy $[9,10]$, i.e. (i) independent sample t-tests to assess whether there was a difference between group and individual INTER-NDA domain scores within subjects; (ii) biases and limits of agreement statistics; (iii) Bland-Altman plots to identify whether INTER-NDA domain scores differed systematically between the group and individual assessments, and (iv) linear regression analyses of the relationship between the difference score and mean of the group and individual assessments.

Descriptive statistics were calculated for weight, length, head circumference and age at the time of assessment. A covariate analysis was carried out to determine whether weight, length, head circumference, child age and sex, and location of the preschool were associated with mean INTER-NDA scores for group and individual assessments separately. T tests, ANOVAs and continuous correlations were used to examine the effect of: (i) sex; (ii) location of preschool, and (iii) age and anthropometry respectively on INTER-NDA scores.

A hierarchical linear regression analysis was conducted to examine associations between type of assessment (group or individual) and INTER-NDA domain scores using potential confounders as covariates. For each INTER-NDA domain, the analysis consisted of four models. In model 1, unadjusted associations between type of assessment and INTER-NDA domain scores are presented. In model 2, the association is further adjusted for the age and sex of the children. In model 3 , the association is adjusted for the factors in model 2 and the nutritional status of the children (weight, length and head circumference). In the final model, the association is adjusted for the factors in model 3 together with the location of the preschool.

\section{RESULTS}

Of the 42 children (mean age 2.08 y, SD 0.29) assessed using individual assessments in the study, 26 were girls and 16 were boys. Six of these children were not available for the group assessment; therefore, the study groups consisted of 36 children organized into 12 triads. Ten triads consisted of 2 girls and a boy, and 2 triads consisted of 2 boys and a girl. All children were native in Mexican Spanish and spoke no other languages.

The sequence of the INTER-NDA group assessment for a group of three children is presented in Supporting Information 1. The forms for each child within a group are presented in Supporting Information 2-4. The INTERNDA form for individual assessment is presented in Supporting Information 5 .

The mean weight $(\mathrm{kg})$, length $(\mathrm{cm})$ and head circumference (cm) for the 42 children were 12.06 (1.59), 85.04 (5.23) and 46.68 (3.17) for boys and 11.35 (1.60), 83.44 (4.06) and 45.18 (4.69) for girls, respectively. These mean values corresponded, for both boys and girls, to the $25^{\text {th }}-50^{\text {th }}$ centile, $15^{\text {th }}-25^{\text {th }}$ centile and $5^{\text {th }}-15^{\text {th }}$ centile for weight, length and head circumference respectively on the WHO Child Growth Standards [11].

The mean INTER-NDA domain scores for the sample for group and individual assessments are presented in table 1 , along with the results of the correlational analysis and paired $t$ tests. The results of the correlational analysis found that the mean INTER-NDA domain scores from group and individual assessments were significantly highly correlated for 9 of the 10 domains $(r=0.35$ to 1.00, $\mathrm{p}=0.03$ to<0.001), with actual scores being identical in five domains.

The only domain where the group and individual assessment scores were not significantly correlated was receptive language $(r=0.25, p=0.14)$. Paired t tests did not find any significant differences in INTER-NDA domain scores between group and individual assessments on any domains. The difference between individual and group scores on the fine motor domain approached significance (individual mean 1.46, SD 0.65; group mean 1.24, SD 0.27; $\mathrm{p}=0.05$ ); however, for all other domains the scores were very similar.

Table 1: INTER-NDA domain scores according to method of assessment, correlation analysis between group and individual domain scores and group-individual comparisons

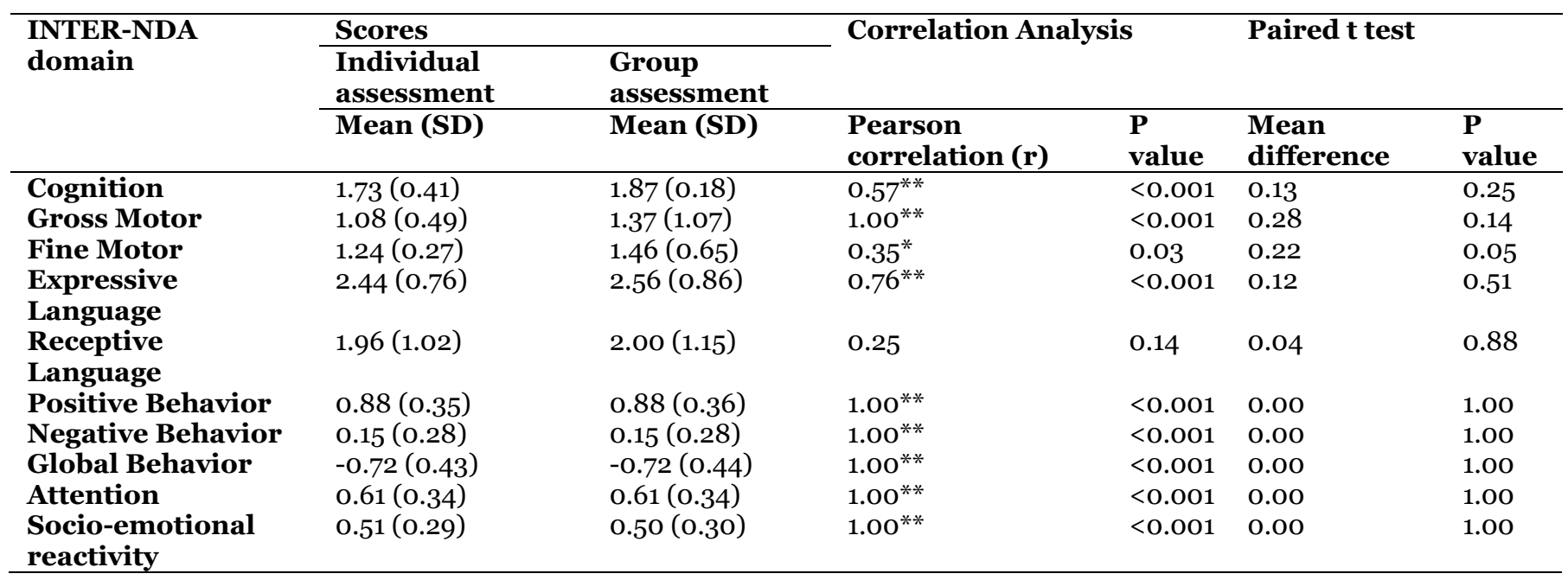

${ }^{*} \mathrm{p}<0.05,{ }^{* *} \mathrm{p}<0.001$ 
The results of the Bland-Altman analysis are presented in table 2 and fig. 1. Independent sample $t$ tests showed no statistically significant differences in INTER-NDA domain scores based on the method of measurement, i.e. group or individual assessment. The analysis indicated no bias (o\%) in the domains of behavior (positive, negative and global) and attention (hence, plots corresponding to fig. 1, for these domains are not shown). Bias was very low in the domains of expressive language (2.2\%), receptive language $(2.9 \%)$ and socio-emotional reactivity (0.04\%). Bias was moderate in the domains of cognition (27.0\%), gross motor skills (16.1\%) and fine motor skills (14.3\%).

The results of the linear regression showed a significant linear association between group and individual scores on these domains. Taken together, these results suggest that the cognition, gross and fine motor scores for group and individual assessments are positively correlated but not numerically in agreement. Scores on all other domains are numerically in agreement. This is further illustrated in the Bland-Altman plots (fig. 1).

For all plots, the central horizontal line represents the mean difference, and the two other horizontal lines represent the upper and lower limits of agreement, respectively. The sample size was 36 for all plots. Examples of the variability observed in the Bland Altman plots are shown for (A) cognition, (B) fine motor, (C) expressive language, (D) receptive language, and (E) socio-emotional reactivity domains. No plots are depicted for behavior (positive, negative and global) and attention because the BlandAltman analysis indicated no bias at all (o\%) in these domains. For gross motor, the scores were identical for 31 of the 36 children; hence, the plot is not presented either.

The results of the exploratory covariate analysis found significant association between INTER-NDA scores and location of preschool, age and anthropometric measures; hence, these were included as covariates in the regression analysis. Although no association with sex was found, sex was included as a covariate in the analysis based on evidence from the literature that neurodevelopment scores can differ between boys and girls [12-14].

Table 3 reports the results of the multiple linear regression analysis examining the association of the mode of the assessment (group or individual) on mean INTER-NDA domain scores after adjusting for age, sex, weight, length, head circumference and preschool location (further information on the covariate analysis is presented in S6). For all domains, there were no significant differences between scores obtained from group and individual assessments. The only near significant difference between group and individual scores was for the gross motor domain, which reached $\mathrm{p}=0.05$ level after adjusting for the confounding variables.

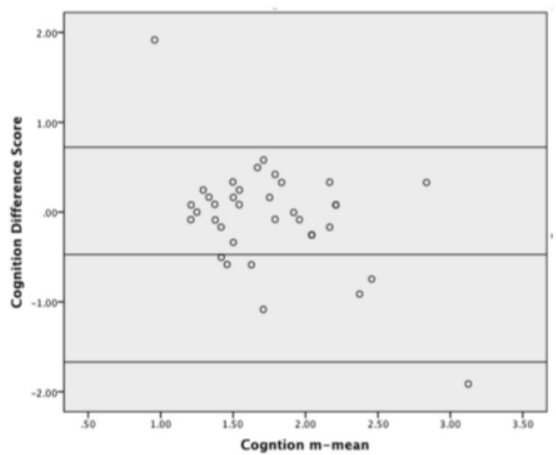

(A)

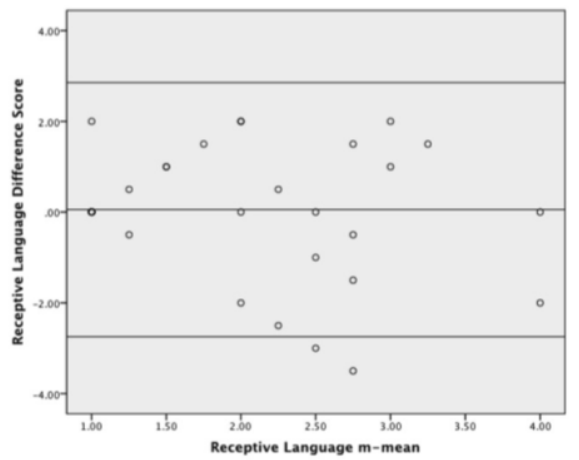

(D)

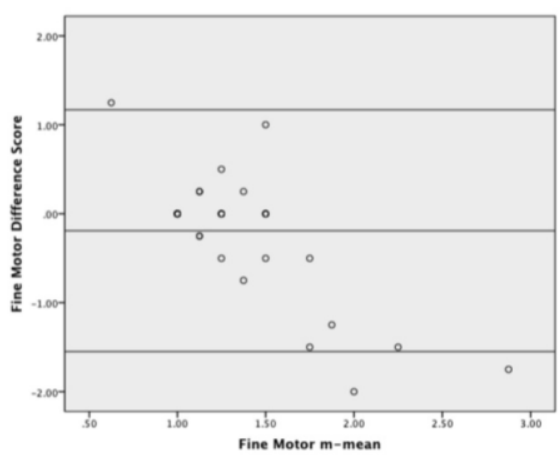

(B)

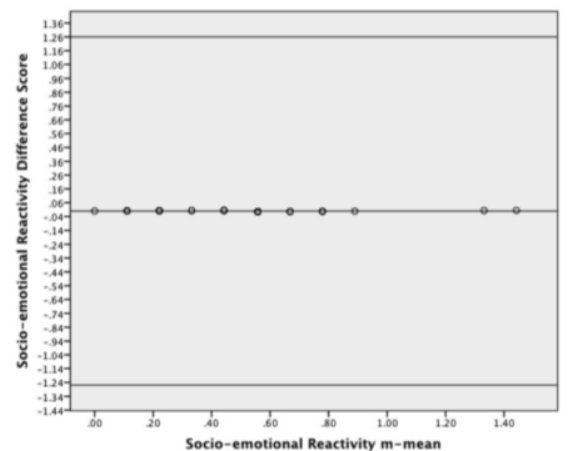

(E)

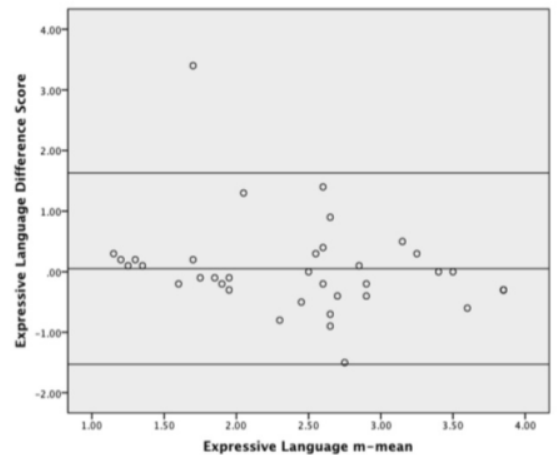

(C)

Fig. 1: Bland-Altman plots for the INTER-NDA cognitive, motor, language and socio-emotional reactivity domains 
Table 2: Bland-Altman analysis for the comparison between individual and group assessments scores

\begin{tabular}{|c|c|c|c|c|c|c|c|c|}
\hline \multirow[t]{2}{*}{$\begin{array}{l}\text { INTER- } \\
\text { NDA } \\
\text { domain }\end{array}$} & \multicolumn{3}{|c|}{ One sample $t$ test } & \multicolumn{3}{|c|}{ Bland-Altman Statistics } & \multicolumn{2}{|c|}{$\begin{array}{l}\text { Linear regression (difference } \\
\text { scores vs. mean of group and } \\
\text { individual scores) }\end{array}$} \\
\hline & $\begin{array}{l}\text { Mean } \\
\text { difference }\end{array}$ & $\begin{array}{l}\text { SD } \\
\text { difference }\end{array}$ & Sig. & $\begin{array}{l}\text { Bias } \\
(\%)\end{array}$ & $\begin{array}{l}\text { Lower } \\
\text { Limit of } \\
\text { Agreement }\end{array}$ & $\begin{array}{l}\text { Upper } \\
\text { limit of } \\
\text { agreement }\end{array}$ & B & p \\
\hline Cognition & -0.47 & 0.59 & 0.64 & 27.02 & -1.67 & 0.72 & -0.61 & $0.003^{*}$ \\
\hline Gross Motor & -0.19 & 1.19 & 0.33 & 16.10 & -2.57 & 2.19 & -1.43 & $<0.001^{* *}$ \\
\hline Fine Motor & -0.19 & 0.68 & 0.09 & 14.28 & -1.55 & 1.17 & -1.23 & $<0.001^{* *}$ \\
\hline $\begin{array}{l}\text { Expressive } \\
\text { Language }\end{array}$ & 0.05 & 0.79 & 0.69 & 2.16 & -1.53 & 1.63 & -0.25 & 0.16 \\
\hline $\begin{array}{l}\text { Receptive } \\
\text { Language }\end{array}$ & 0.06 & 1.40 & 0.81 & 2.90 & -2.74 & 2.85 & -0.28 & 0.30 \\
\hline $\begin{array}{l}\text { Positive } \\
\text { Behavior }\end{array}$ & 0.00 & 0.00 & $\mathrm{n} / \mathrm{a}$ & 0.00 & $\mathrm{n} / \mathrm{a}$ & $\mathrm{n} / \mathrm{a}$ & $\mathrm{n} / \mathrm{a}$ & $\mathrm{n} / \mathrm{a}$ \\
\hline $\begin{array}{l}\text { Negative } \\
\text { Behavior }\end{array}$ & 0.00 & 0.00 & $\mathrm{n} / \mathrm{a}$ & 0.00 & $\mathrm{n} / \mathrm{a}$ & $\mathrm{n} / \mathrm{a}$ & $\mathrm{n} / \mathrm{a}$ & $\mathrm{n} / \mathrm{a}$ \\
\hline $\begin{array}{l}\text { Global } \\
\text { Behavior }\end{array}$ & 0.00 & 0.00 & $\mathrm{n} / \mathrm{a}$ & 0.00 & $\mathrm{n} / \mathrm{a}$ & $\mathrm{n} / \mathrm{a}$ & $\mathrm{n} / \mathrm{a}$ & $\mathrm{n} / \mathrm{a}$ \\
\hline Attention & 0.00 & 0.00 & $\mathrm{n} / \mathrm{a}$ & 0.00 & $\mathrm{n} / \mathrm{a}$ & $\mathrm{n} / \mathrm{a}$ & $\mathrm{n} / \mathrm{a}$ & $\mathrm{n} / \mathrm{a}$ \\
\hline $\begin{array}{l}\text { Socio- } \\
\text { emotional } \\
\text { reactivity }\end{array}$ & 0.0002 & 0.003 & 0.63 & 0.04 & -1.26 & 1.26 & 0.002 & 0.27 \\
\hline
\end{tabular}

${ }^{*} \mathrm{p}<0.05,{ }^{* *} \mathrm{p}<0.001 . \mathrm{n} / \mathrm{a}=$ analysis not applicable as values are identical.

Table 3: Comparison between individual and group assessments scores: Multiple variable regression analysis

\begin{tabular}{|c|c|c|c|c|c|c|c|c|}
\hline \multirow[t]{2}{*}{$\begin{array}{l}\text { INTER- } \\
\text { NDA } \\
\text { domain }\end{array}$} & \multicolumn{2}{|c|}{ Unadjusted } & \multicolumn{2}{|c|}{$\begin{array}{l}\text { Adjusted for age } \\
\text { and sex }\end{array}$} & \multicolumn{2}{|c|}{$\begin{array}{l}\text { Adjusted for age, sex } \\
\text { and nutritional } \\
\text { status }\end{array}$} & \multicolumn{2}{|c|}{$\begin{array}{l}\text { Adjusted for age, sex, } \\
\text { nutritional status and } \\
\text { preschool location }\end{array}$} \\
\hline & B (SE) & $\mathbf{p}$ & B (SE) & $\mathbf{p}$ & B (SE) & $\mathbf{p}$ & B (SE) & $\mathbf{p}$ \\
\hline Cognition & $\begin{array}{l}-1.62 \\
(1.49)\end{array}$ & 0.28 & $\begin{array}{l}-1.32 \\
(1.42)\end{array}$ & 0.35 & $\begin{array}{l}-1.26 \\
(1.34)\end{array}$ & 0.35 & $\begin{array}{l}-1.27 \\
(1.35)\end{array}$ & 0.35 \\
\hline $\begin{array}{l}\text { Gross } \\
\text { Motor }\end{array}$ & $\begin{array}{l}-0.79 \\
(0.39)\end{array}$ & $0.04 *$ & $\begin{array}{l}-0.80 \\
(0.39)\end{array}$ & 0.05 & $\begin{array}{l}-0.78 \\
(0.39)\end{array}$ & 0.05 & $\begin{array}{l}-0.79 \\
(0.39)\end{array}$ & 0.05 \\
\hline Fine Motor & $\begin{array}{l}-0.92 \\
(0.49)\end{array}$ & 0.07 & $\begin{array}{l}-0.87 \\
(0.49)\end{array}$ & 0.08 & $\begin{array}{l}-0.86 \\
(0.48)\end{array}$ & 0.08 & $\begin{array}{l}-0.87 \\
(0.47)\end{array}$ & 0.07 \\
\hline $\begin{array}{l}\text { Expressive } \\
\text { Language }\end{array}$ & $\begin{array}{l}-1.37 \\
(2.19)\end{array}$ & 0.54 & $\begin{array}{l}-0.73 \\
(1.77)\end{array}$ & 0.68 & $\begin{array}{l}-0.76 \\
(1.73)\end{array}$ & 0.66 & $\begin{array}{l}-0.72 \\
(1.67)\end{array}$ & 0.67 \\
\hline $\begin{array}{l}\text { Receptive } \\
\text { Language }\end{array}$ & $\begin{array}{l}-0.19 \\
(0.52)\end{array}$ & 0.71 & $\begin{array}{l}-0.11 \\
(0.51)\end{array}$ & 0.83 & $\begin{array}{l}-0.14 \\
(0.49)\end{array}$ & 0.78 & $\begin{array}{l}-0.14 \\
(0.49)\end{array}$ & 0.79 \\
\hline $\begin{array}{l}\text { Positive } \\
\text { Behavior }\end{array}$ & $\begin{array}{l}-0.02 \\
(0.37)\end{array}$ & 0.96 & $\begin{array}{l}0.01 \\
(0.38)\end{array}$ & 0.97 & $\begin{array}{l}0.03 \\
(4.02)\end{array}$ & 0.94 & $\begin{array}{l}0.03 \\
(0.38)\end{array}$ & 0.94 \\
\hline $\begin{array}{l}\text { Negative } \\
\text { Behavior }\end{array}$ & $\begin{array}{l}0.03 \\
(0.12)\end{array}$ & 0.79 & $\begin{array}{l}0.04 \\
(0.12)\end{array}$ & 0.77 & $\begin{array}{l}0.04 \\
(0.12)\end{array}$ & 0.78 & $\begin{array}{l}0.03 \\
(0.12)\end{array}$ & 0.78 \\
\hline $\begin{array}{l}\text { Global } \\
\text { Behavior }\end{array}$ & $\begin{array}{l}0.02 \\
(0.11)\end{array}$ & 0.86 & $\begin{array}{l}0.02 \\
(0.11)\end{array}$ & 0.89 & $\begin{array}{l}0.01 \\
(0.11)\end{array}$ & 0.90 & $\begin{array}{l}0.01 \\
(0.11)\end{array}$ & 0.91 \\
\hline Attention & $\begin{array}{l}-0.04 \\
(0.37)\end{array}$ & 0.91 & $\begin{array}{l}0.02 \\
(0.36)\end{array}$ & 0.96 & $\begin{array}{l}0.02 \\
(0.36)\end{array}$ & 0.95 & $\begin{array}{l}0.02 \\
(0.36)\end{array}$ & 0.95 \\
\hline $\begin{array}{l}\text { Socio- } \\
\text { emotional } \\
\text { reactivity }\end{array}$ & $\begin{array}{l}0.01 \\
(0.57)\end{array}$ & 0.98 & $\begin{array}{l}0.02 \\
(0.58)\end{array}$ & 0.97 & $\begin{array}{l}0.06 \\
(0.55)\end{array}$ & 0.90 & $\begin{array}{l}0.07 \\
(0.55)\end{array}$ & 0.90 \\
\hline
\end{tabular}

All are Unstandardized beta coefficients, ${ }^{*} \mathrm{p}<0.05$

\section{DISCUSSION}

Through several complementary statistical strategies, we have demonstrated consistent similarities and lack of differences between group and individual INTER-NDA domain scores. Scores for group and individual assessments were significantly correlated for all domains, except receptive language. There were no significant differences between scores obtained from group and individual assessments following inter-group comparisons. The results of the Bland-Altman analysis showed agreement between group and individual scores for the language, behavior, attention and socio-emotional reactivity domains, as well as consistency (but not agreement) between group and individual scores for the cognitive and motor domains. None 
of the differences between the two assessment strategies examined in the Bland Altman analysis were statistically significant. Adjusting for the age, sex, nutritional status of the children and preschool location did not change these results. Hence, we conclude there is strong preliminary evidence that the INTER-NDA may be used to assess ECD outcomes in groups of three children within a preschool setting, giving test scores comparable to those obtained from individual assessment.

Although no statistically significant differences between group and individual scores were detected, the scores for cognitive, language and motor domains were higher for the group assessment than those for individual children. This finding may reflect the better performance of children when assessed in a group or an imitation effect.

Although there are no previous reports of group ECD assessments, the group-based approach has been applied, to good effect, in the implementation of ECD interventions such as play therapy, physical education and cognitive behavior therapy (CBT) among children with Asperger syndrome, language disorders and anxiety [15-17]. These studies have shown significant improvement in development skill scores among children who received group-based therapies[15-17]. The present study is, to our knowledge, the first to apply a group strategy to ECD assessment. Moreover, group and individual assessments were conducted by pre-school teachers with a secondary education degree, specifically trained and standardized in how to administer and score the INTER-NDA.

Importantly, the INTER-NDA could easily be adapted for group assessment because of a number of features: (i) it is easy and quick to administer; (ii) its items are free from cultural and gender bias; (iii) it is based on objective reporting (rather than subjective judgment) of the child's performance, and (iv) each item is reported on a 5-point scale, which includes options for 'no attempt' and 'unable to assess' [5]. Nevertheless, our group assessment protocol has been applied only to groups of three children; in its current form, it may not be applicable to larger groups.

Our study is limited in that the teacher who carried out the individual assessment was present in the room during the group assessment and was, therefore, not blind to the child's performance during the group assessment. Six of the children participating in the individual assessments did not return for the group assessment resulting in an imbalance of male-female ratios in the triads, meaning that an analysis by sex is beyond the scope of this study. Children were assessed on the INTER-NDA in two different formats within a 2-day period. It is possible that repeating the same items within a short span of time could result in familiarity and learning biases during subsequent assessments. In an effort to minimize these effects, we introduced variations in the order of testing between the group and individual assessments; however, the effects of these biases cannot be wholly eliminated.

From an implementation perspective, the preschool teachers neither reported difficulty with the administration of items to three children during the group assessment, nor did they report interference between children. They reported that children tended to encourage each other during the group assessment, and that this expedited the child's assessment on expressive language and gross motor items. The overall impression of the observers was that children tended to be more reserved during individual, compared to group, assessment. The individual and group assessments took approximately 15 and $40 \mathrm{~min}$, respectively. An optimistic interpretation of this feedback might suggest that assessments in the preschool environments, with peers, are closer to the real-life context of children. We believe that it is important, in the group assessment, for children to be assessed by a person, and in the company of peers, with whom they are already familiar. The preschool may, therefore, provide an ideal setting for group-based ECD assessment by teachers.

Our study was conducted in Mexico among lowermiddle class children. In the situation commonly encountered globally, where resources for ECD assessment and intervention are limited, it may be possible to harness the expertise of preschool teachers to enable preschools to function as population-level sites for multi-domain ECD assessment (i.e., beyond that of routine observation of gross motor skills). This may provide a possible solution to one of the ratelimiting steps in population-based ECD assessment, i.e. its dependence on specialized personnel.

In conclusion, we have shown that INTER-NDA domain scores obtained following group and individual assessment of 22 to 26 months old preschool children are comparable. Furthermore, we have demonstrated that is feasible for preschool teachers to administer both group and individual INTER-NDA assessments. These results, if replicated, could strengthen the INTER-NDA's ability to be used as a rapid, scalable ECD assessment tool for field research projects and first level screening strategy at population level.

\section{ACKNOWLEDGEMENT}

The authors are grateful to the members of the INTERGROWTH-21 ${ }^{\text {st }}$ Neurodevelopment scientific advisory panel for their intellectual and technical contribution to the INTER-NDA. The authors gratefully acknowledge the parents, teachers and children participating in this study. This study was supported by INTERGROWTH-21 ${ }^{\text {st }}$ grant 49038 from the Bill and Melinda Gates Foundation to the University of Oxford.

\section{AUTHORS CONTRIBUTIONS}

Conceived and designed the study: JS. Performed the study: SS LCI MF PVA MF GGV FC MLLG ABD JS. Analyzed the data: MF JV AS. Contributed reagents/materials/analysis tools: AS SK. Wrote the paper: MF JV AS SK with JS and GGV.

\section{COMPETING INTERESTS}

The authors have read the Journal's policy and declare the following competing interests: G. Guerrero Varela, F. Hernandez Castillo, M. de la Luz Lozada Guzmán and A. Buchán Durán are employed by Programa Educación Inicial, Fundacion C. Slim, Mexico. L. Cheikh Ismail and M Fernandes are members of the Editorial Board of the Journal. This does not alter the authors' adherence to the IJGD's policies on sharing data and materials.

\section{REFERENCES}

1. Black MM, Walker SP, Fernald LCH, Andersen CT, Digirolamo AM, Lu C, Et al. Early Childhood Development Coming Of Age: Science Through The Life Course. Lancet. 2016;389(10064):77-90. Doi: 10.1016/So140-673631389-7. 
2. Bayley N. Bayley Scales Of Infant And Toddler Development, Third Edition. San Antonio, TX: Pearson Education Inc.; 2006.

3. Griffiths R. The Abilities Of Babies: A Study In Mental Measurement. New York, NY, US: Mcgraw-Hill; 1954. 229 P.

4. Frankenburg WK, Dodds JB. The Denver Developmental Screening Test. J Pediatr. 1967;71:18191. Doi: 10.1016/So022-347680070-2

5. Fernandes M, Stein A, Newton CRJ, Ismail LC, Kihara M, Wulff K, Et al. The INTERGROWTH-21 ${ }^{\text {st }}$ Project Neurodevelopment Package: A Novel Method For The Multi-Dimensional Assessment Of Neurodevelopment In Pre-School Age Children Plos ONE. 2014;9(: E113360). Epub 25 November 2014. Doi: 10.1371/Journal. Pone.011336o.

6. Villar J, Altman DG, Purwar M, Noble JA, Knight HE, Ruyan P, Et al. The Objectives, Design And Implementation Of The INTERGROWTH-21 ${ }^{\text {st }}$ Project. BJOG 2013;120:9-26. Doi: 10.1111/1471-0528.12047.

7. Harkness J, Pennell B, Villar A, Gebler N, AguilarGaxiola S, Bilgen I. Translation Procedures And Translation Assessment In The World Mental Health Survey Initiative. The WHO World Mental Health Surveys: Global Perspectives On The Epidemiology Of Mental Disorders. 2008:91-113.

8. International Fetal And Newborn Growth Standards For The $21^{\text {st }}$ Century Anthropometry Handbook [Electronic]. Oxford, UK2012. Available From: Https://Www. Medscinet. Net/Intergrowth/Patientinfodocs/Anthropometry Handbook April 2012. Pdf.

9. Bland JM, Altman DG. A Note On The Use Of The Intraclass Correlation Coefficient In The Evaluation Of Agreement Between Two Methods Of Measurement. Comput Biol Med. 1990;20:337-40. Doi: 10.1016/0010-482590013-F.
10. Martin Bland J, Altman D. Statistical Methods For Assessing Agreement Between Two Methods Of Clincal Measurement Lancet. 1986;327(8476):307-10. Doi: 10.1016/So140-673690837-8.

11. Who Multicentre Growth Reference Study Group. WHO Child Growth Standards Based On Length/Height, Weight And Age. Acta Pædiatr Suppl. 2006;95:76-85. Doi: 10.1111/J.1651-2227.2006. Tbo2378. X.

12. Kochanska G, Murray KT, Harlan ET. Effortful Control In Early Childhood: Continuity And Change, Antecedents, And Implications For Social Development. Dev Psychol. 2000;36:220-32. Doi: 10.1037/0012-1649.36.2.220

13. Huttenlocher J, Haight W, Bryk A, Seltzer M, Lyons T. Early Vocabulary Growth: Relation To Language Input And Gender. Dev Psychol. 1991;27:236-48. Doi: 10.1037/0012-1649.27.2.236

14. Thomas JR, French KE. Gender Differences Across Age In Motor Performance: A Meta-Analysis. Psychol Bull. 1985;98:260-82. Doi: 10.1037/00332909.98.2.260

15. Beaumont R, Sofronoff K. A Multi-Component Social Skills Intervention For Children With Asperger Syndrome: The Junior Detective Training Program. J Child Psychol Psychiatry. 2008;49:743-53. Doi: 10.1111/J.1469-7610.2008.01920. X

16. Rintala $\mathrm{P}$, Pienimäki K, Ahonen T, Cantell M, Kooistra L. The Effects Of A Psychomotor Training Programme On Motor Skill Development In Children With Developmental Language Disorders. Hum Mov Sci. 1998;17(4-5):721-37. Doi: 10.1016/So167-9457000219.

17. Monga S, Young A, Owens M. Evaluating A Cognitive Behavioral Therapy Group Program For Anxious Five To Seven Year Old Children: A Pilot Study. Depress Anxiety. 2009;26:243-50. Doi: 10.1002/Da.20551 


\section{Supplementary Files}

\section{S1 INTER-NDA sequence for group assessment}

This order of items is designed specifically for the assessment of 3 children simultaneously by a single assessor and as ingle scorer. This proforma is not suitable for group assessments involving more than 3 children.

In the first sequence i.e. sequence no. 1-21, the order of the items is different for different children - hence the assessor must pay more attention to the administration of these items and also practice this part of the assessment more until the assessor is fluent in the administration of the items in this sequence. The assessor MUST assess all children in this sequence and never change this sequence. The scorer must also pay attention to this sequence. Sequence numbers 22-53 are not administered but either maternal report or concurrently observed items, and so these can be scored simultaneously for all children.

\begin{tabular}{|c|c|c|c|}
\hline \multirow{2}{*}{$\begin{array}{l}\text { Sequence of } \\
\text { administration }\end{array}$} & Child 1 & Child 2 & Child 3 \\
\hline & Item number & Item number & Item number \\
\hline $\mathbf{1}$ & $\mathbf{1}$ & 2 & 3 \\
\hline 2 & 4 & 5 & 8 \\
\hline 3 & 2 & 3 & 1 \\
\hline 4 & 5 & 8 & 4 \\
\hline 5 & 3 & $\mathbf{1}$ & 2 \\
\hline 6 & 8 & 4 & 5 \\
\hline 7 & 6 & 7 & 9 \\
\hline 8 & 10 & 11 & 15 \\
\hline 9 & 7 & 9 & 6 \\
\hline 10 & 11 & 15 & 10 \\
\hline 11 & 9 & 6 & 7 \\
\hline 12 & 15 & 10 & 11 \\
\hline 13 & 12 & 13 & 14 \\
\hline 14 & 16 & 17 & 30 \\
\hline 15 & 13 & 14 & 12 \\
\hline 16 & 17 & 30 & 16 \\
\hline 17 & 14 & 12 & 13 \\
\hline 18 & 30 & 16 & 17 \\
\hline 19 & 19 & 20 & 21 \\
\hline 20 & 20 & 21 & 19 \\
\hline 21 & 21 & 19 & 20 \\
\hline 22 & 18 & 18 & 18 \\
\hline 23 & 22 & 22 & 22 \\
\hline 24 & 23 & 23 & 23 \\
\hline 25 & 24 & 24 & 24 \\
\hline 26 & 25 & 25 & 25 \\
\hline 27 & 26 & 26 & 26 \\
\hline 28 & 27 & 27 & 27 \\
\hline 29 & 28 & 28 & 28 \\
\hline 30 & 29 & 29 & 29 \\
\hline 31 & 31 & 31 & 31 \\
\hline 32 & 32 & 32 & 32 \\
\hline 33 & 33 & 33 & 33 \\
\hline 34 & 34 & 34 & 34 \\
\hline 35 & 35 & 35 & 35 \\
\hline 36 & 36 & 36 & 36 \\
\hline 37 & 37 & 37 & 37 \\
\hline 38 & 38 & 38 & 38 \\
\hline 39 & 39 & 39 & 39 \\
\hline 40 & 40 & 40 & 40 \\
\hline 41 & 41 & 41 & 41 \\
\hline 42 & 42 & 42 & 42 \\
\hline 43 & 43 & 43 & 43 \\
\hline 44 & 44 & 44 & 44 \\
\hline 45 & 45 & 45 & 45 \\
\hline 46 & 46 & 46 & 46 \\
\hline 47 & 47 & 47 & 47 \\
\hline 48 & 48 & 48 & 48 \\
\hline 49 & 49 & 49 & 49 \\
\hline 50 & 50 & 50 & 50 \\
\hline 51 & 51 & 51 & 51 \\
\hline 52 & 52 & 52 & 52 \\
\hline 53 & 53 & 53 & 53 \\
\hline
\end{tabular}




\section{Child 1 - GROUP ASSESSMENT}

\section{Name:}

Study Number:

Assessor:

Scorer:

\begin{tabular}{|c|c|c|c|c|c|c|}
\hline \multirow{3}{*}{ No. } & \multirow{2}{*}{ Item } & \multirow{2}{*}{\multicolumn{5}{|c|}{ Observed performance }} \\
\hline & & & & & & \\
\hline & Builds a tower of 5 cubes (trials $=3$, demonstration $=3$ ) & 5 cubes & 3-4 cubes & 2 cubes & No attempt & Unable to assess \\
\hline 4 & $\begin{array}{l}\text { Hands the examiner one cube when asked to do so (Examiner } \\
\text { says "Please give me one cube" \& keeps palm open for } 5 \\
\text { seconds after child has handed over } 1 \text { cube) (trials }=1 \text {, } \\
\text { demonstration }=0 \text { ) }\end{array}$ & $\begin{array}{l}\text { Hands only one } \\
\text { block within } 5 \\
\text { seconds }\end{array}$ & $\begin{array}{l}\text { Hands only one } \\
\text { block in more than } \\
5 \text { seconds }\end{array}$ & $\begin{array}{l}\text { Hands two or more } \\
\text { blocks }\end{array}$ & $\begin{array}{l}\text { Does not hand } \\
\text { any block / No } \\
\text { attempt }\end{array}$ & Unable to assess \\
\hline 2 & $\begin{array}{l}\text { Names } 4 \text { colours when asked to do so (trials }=1 \text {, } \\
\text { demonstration }=0 \text { ) }\end{array}$ & Names 4 colours & Names 3 colours & $\begin{array}{l}\text { Names } 1 \text { or } 2 \\
\text { colours }\end{array}$ & $\begin{array}{l}\text { Does not name } \\
\text { any colour }\end{array}$ & Unable to assess \\
\hline 5 & $\begin{array}{l}\text { Puts the spoon in the cup when asked to do so (trials }=5 \text {, } \\
\text { demonstration }=O \text { ) }\end{array}$ & $\begin{array}{l}\text { Puts the spoon in } \\
\text { cup in } \leq 3 \text { trials }\end{array}$ & $\begin{array}{l}\text { Puts the spoon in } \\
\text { cup in } 4-5 \text { trials }\end{array}$ & $\begin{array}{l}\text { Takes the spoon or } \\
\text { the cup but does } \\
\text { not complete action }\end{array}$ & No attempt & Unable to assess \\
\hline 3 & $\begin{array}{l}\text { Matches } 3 \text { cubes of same colours when requested to do so } \\
\text { (trials }=1 \text {, demonstration=1 of one colour) }\end{array}$ & $\begin{array}{l}\text { Matches } 3 \\
\text { colours }\end{array}$ & Matches 2 colours & Matches 1 colour & $\begin{array}{l}\text { Does not match } \\
\text { any colour }\end{array}$ & Unable to assess \\
\hline 8 & $\begin{array}{l}\text { Points correctly when asked "Where is the door/entrance to } \\
\text { the room?" (trials }=5 \text {, demonstration }=O \text { ) }\end{array}$ & $\begin{array}{l}\text { Identifies door } \\
\text { correctly in } \leq 3 \\
\text { trials }\end{array}$ & $\begin{array}{l}\text { Identifies door } \\
\text { correctly in 4-5 } \\
\text { trials }\end{array}$ & $\begin{array}{l}\text { Attempts, but does } \\
\text { not identify door }\end{array}$ & No attempt & Unable to assess \\
\hline 6 & $\begin{array}{l}\text { Matches shapes on board (trials }=5 \text {, demonstration=partial }- \\
\text { removal only) }\end{array}$ & $\begin{array}{l}\text { All shapes in } \leq 3 \\
\text { trials }\end{array}$ & $\begin{array}{l}\text { All shapes with } \\
\text { repeated } \\
\text { demonstration i.e. } \\
4-5 \text { trials }\end{array}$ & $\begin{array}{l}\text { One or two shapes } \\
\text { in } 4-5 \text { trials }\end{array}$ & No attempt & Unable to assess \\
\hline 10 & $\begin{array}{l}\text { Drinks water from cup/bottle/sippy cup when placed in front } \\
\text { of child (trials=1, maternal recall if observation not possible) }\end{array}$ & $\begin{array}{l}\text { Drinks water } \\
\text { from cup/sippy } \\
\text { cup without } \\
\text { spilling }\end{array}$ & $\begin{array}{l}\text { Drinks clumsily \& } \\
\text { spills }\end{array}$ & $\begin{array}{l}\text { Attempts but } \\
\text { unsuccessful }\end{array}$ & No attempt & Unable to assess \\
\hline 7 & $\begin{array}{l}\text { Matches shapes on rotated board (trials }=5 \text {, demonstration } \\
=\text { partial }- \text { removal only) }\end{array}$ & $\begin{array}{l}\text { All shapes in } \leq 3 \\
\text { trials }\end{array}$ & $\begin{array}{l}\text { All shapes with } \\
\text { repeated } \\
\text { demonstration i.e. } \\
4-5 \text { trials }\end{array}$ & $\begin{array}{l}\text { One or two shapes } \\
\text { in } 4-5 \text { trials }\end{array}$ & No attempt & Unable to assess \\
\hline
\end{tabular}




\begin{tabular}{|c|c|c|c|c|c|c|}
\hline 11 & $\begin{array}{l}\text { Looks towards an object located across the room when pointed } \\
\text { at by the examiner (trials }=5 \text { ) }\end{array}$ & $\begin{array}{l}\text { Looks or points at } \\
\text { object in } \leq 3 \text { trials }\end{array}$ & $\begin{array}{l}\text { Looks or points at } \\
\text { object in } 4-5 \text { trials }\end{array}$ & $\begin{array}{l}\text { Looks at the wrong } \\
\text { object, or attempts } \\
\text { but cannot identify } \\
\text { object }\end{array}$ & No attempt & Unable to assess \\
\hline 9 & $\begin{array}{l}\text { Puts a raisin precisely inside a small opening in a bottle } \\
\text { (trials }=1 \text {, demonstration }=1 \text {; test both hands) }\end{array}$ & $\begin{array}{l}\text { Precise release of } \\
\text { raisin into bottle } \\
\text { with each hand }\end{array}$ & $\begin{array}{l}\text { Clumsy release, } \\
\text { raisin falls out of } \\
\text { bottle with one or } \\
\text { more hand }\end{array}$ & $\begin{array}{l}\text { Attempts but } \\
\text { unsuccessful } \\
\text { release with one or } \\
\text { more hand }\end{array}$ & No attempt & Unable to assess \\
\hline 15 & $\begin{array}{l}\text { Imitates straight horizontal scribble (trials }=5 \text {, } \\
\text { demonstration }=5 \text { ) }\end{array}$ & $\leq 3$ trials & $\begin{array}{l}4-5 \text { trials; with } \\
\text { difficulty }\end{array}$ & $\begin{array}{l}\text { Attempts (hold } \\
\text { crayon) }\end{array}$ & $\begin{array}{l}\text { Cannot hold } \\
\text { crayon }\end{array}$ & Unable to assess \\
\hline 12 & $\begin{array}{l}\text { Pretends to drink from a toy cup when placed in front of } \\
\text { him/her (trials=2, demonstration=1 if not spontaneous on } \\
\text { first attempt) }\end{array}$ & Spontaneously & $\begin{array}{l}\text { After } 1 \\
\text { demonstration }\end{array}$ & $\begin{array}{l}\text { Partial attempt } \\
\text { after } 1 \\
\text { demonstration }\end{array}$ & No attempt & Unable to assess \\
\hline 16 & $\begin{array}{l}\text { Identifies glitter bracelet under correct washcloth (trials }=5 \text {, } \\
\text { demonstration }=0 \text {, test both sides) }\end{array}$ & $\begin{array}{l}\text { Finds bracelet } \\
\text { correctly in } \leq 2 \\
\text { trails on both } \\
\text { sides }\end{array}$ & $\begin{array}{l}\text { Find bracelet } \\
\text { correctly in } 3 \text { trials } \\
\text { or on one side } \\
\text { only }\end{array}$ & $\begin{array}{l}\text { Find bracelet } \\
\text { correctly in } 4-5 \\
\text { trials or on one side } \\
\text { only }\end{array}$ & $\begin{array}{l}\text { Does not find } \\
\text { bracelet or no } \\
\text { attempt }\end{array}$ & Unable to assess \\
\hline 13 & $\begin{array}{l}\text { Able to make a cup of tea with the toy tea set when requested } \\
\text { by examiner (Examiner says "Can you make a cup of tea?") } \\
\text { (trials }=2, \text { demonstration=1 if not spontaneous on first } \\
\text { attempt) }\end{array}$ & $\begin{array}{l}\text { Spontaneously, } \\
\text { with pouring } \\
\text { motion }\end{array}$ & $\begin{array}{l}\text { After } 1 \\
\text { demonstration }\end{array}$ & $\begin{array}{l}\text { Partial attempt } \\
\text { after } 1 \\
\text { demonstration }\end{array}$ & No attempt & Unable to assess \\
\hline 17 & $\begin{array}{l}\text { Correctly identifies object groups using plurals (concurrent } \\
\text { observation) }\end{array}$ & Uses 5 plurals & Uses 3-4 plurals & Uses 1-2 plurals & $\begin{array}{l}\text { Does not use } \\
\text { any plurals }\end{array}$ & Unable to assess \\
\hline 14 & $\begin{array}{l}\text { Feeds doll when requested to (Examiner says "Can you give } \\
\text { the dolly some tea?") (trials }=2, \text { demonstration=1 if not } \\
\text { spontaneous on first attempt) }\end{array}$ & Spontaneously & $\begin{array}{l}\text { After } 1 \\
\text { demonstration }\end{array}$ & $\begin{array}{l}\text { Partial attempt } \\
\text { after } 1 \\
\text { demonstration }\end{array}$ & No attempt & Unable to assess \\
\hline 30 & $\begin{array}{l}\text { Combines word and gesture when asked (trials }=3 \text {, Do Not } \\
\text { demonstrate, use different example if mother says child does } \\
\text { not know the one you are asking) }\end{array}$ & $\begin{array}{l}\text { Combines word } \\
\text { and gesture } \\
\text { completely and } \\
\text { appropriately } \\
\end{array}$ & $\begin{array}{l}\text { Combines word } \\
\text { and gesture } \\
\text { completely but } \\
\text { inappropriately }\end{array}$ & $\begin{array}{l}\text { Combines word } \\
\text { and gesture } \\
\text { incompletely and } \\
\text { inappropriately }\end{array}$ & None & Unable to assess \\
\hline 19 & Runs (maternal recall) & Runs steadily & Attempts & Walks only & $\begin{array}{l}\text { Walks with } \\
\text { support }\end{array}$ & Unable to assess \\
\hline 20 & $\begin{array}{l}\text { Throws a ball very near (trials }=1 \text {, demonstration }=1 \text {, test both } \\
\text { hands) }\end{array}$ & Good release & Unsteady release & Attempts & No attempt & Unable to assess \\
\hline 21 & Kicks ball (maternal recall) & $\begin{array}{l}\text { Kicks ball with } \\
\text { knee flexed }\end{array}$ & $\begin{array}{l}\text { Runs after ball \& } \\
\text { attempts kicking it }\end{array}$ & $\begin{array}{l}\text { Walks and touches } \\
\text { ball with foot }\end{array}$ & No attempt & Unable to assess \\
\hline 18 & Asks for toilet by gesture or verbally (maternal recall) & Always & Occasionally & $\begin{array}{l}\text { Partial (only for } \\
\text { bowel movement) }\end{array}$ & Never & Unable to assess \\
\hline 22 & $\begin{array}{l}\text { Climbs upstairs holding rail, } 2 \text { feet/stair or in adult fashion } \\
\text { (maternal recall) }\end{array}$ & $\begin{array}{l}\text { Climbs stairs } \\
\text { alone steadily }\end{array}$ & $\begin{array}{l}\text { Climb stairs alone } \\
\text { unsteadily }\end{array}$ & $\begin{array}{l}\text { Climbs stairs with } \\
\text { help (uses railing, } \\
\text { holds adult's hand) }\end{array}$ & No attempt & Unable to assess \\
\hline 23 & $\begin{array}{l}\text { Uses 2-4 syllable babble such as dada, mama but not } \\
\text { specifically to anything or any person (concurrent } \\
\text { observation) }\end{array}$ & Spontaneously & Mimics & $\begin{array}{l}1 \text { syllable babble } \\
\text { e.g. ba, ma, da }\end{array}$ & None & Unable to assess \\
\hline 24 & Use two words together (concurrent observation) & $\begin{array}{l}\text { Two words, } \\
\text { appropriate use }\end{array}$ & $\begin{array}{l}\text { Two words, } \\
\text { inappropriate use }\end{array}$ & $\begin{array}{l}\text { One word, } \\
\text { appropriate use }\end{array}$ & No attempt & Unable to assess \\
\hline
\end{tabular}


Int. J. Growth Dev. 2018, 2: 11-33

http://igdjournal.com/

\begin{tabular}{|c|c|c|c|c|c|c|}
\hline 25 & $\begin{array}{l}\text { Indicates by gesture to say no (maternal recall if not observed } \\
\text { during assessment) }\end{array}$ & $\begin{array}{l}\text { Indicates verbally } \\
\text { or by definite } \\
\text { gesture all the } \\
\text { time }\end{array}$ & $\begin{array}{l}\text { Indicates verbally } \\
\text { or by definite } \\
\text { gesture some of } \\
\text { the time }\end{array}$ & $\begin{array}{l}\text { Attempts, but } \\
\text { incomplete } \\
\text { indication }\end{array}$ & No attempt & Unable to assess \\
\hline 26 & $\begin{array}{l}\text { Use of a pronoun e.g. me, my, she, he, it, I (concurrent } \\
\text { observation) }\end{array}$ & $\begin{array}{l}\geq 1 \text { pronoun in } \\
\text { correct context }\end{array}$ & $\begin{array}{l}\geq 1 \text { pronoun, } \\
\text { incorrect use }\end{array}$ & $\begin{array}{l}\text { Use of proper } \\
\text { names, but not } \\
\text { pronouns }\end{array}$ & No use & Unable to assess \\
\hline 27 & $\begin{array}{l}\text { How many words does the child use during the assessment } \\
\text { other than mama/dada (concurrent observation) }\end{array}$ & $\geq 8$ words & 6-7 words & 4-5 words & $\leq 3$ words & Unable to assess \\
\hline 28 & $\begin{array}{l}\text { How many sentences of } 3 \text { words or more does the child use } \\
\text { during the assessment? (concurrent observation) }\end{array}$ & $\geq 2$ & 1 & $\begin{array}{l}\geq 1 \text { two word } \\
\text { utterance }\end{array}$ & None & Unable to assess \\
\hline 29 & $\begin{array}{l}\text { In how many instances does the child follow on a topic of } \\
\text { conversation providing new information? (concurrent } \\
\text { observation) }\end{array}$ & $\begin{array}{l}\text { At least one, } \\
\text { using } \geq 2 \text { words, } \\
\text { proving correct } \\
\text { information }\end{array}$ & $\begin{array}{l}\text { At least one, uses } \\
\text { single words, } \\
\text { provides correct } \\
\text { information }\end{array}$ & $\begin{array}{l}\text { Uses any number } \\
\text { of words, provides } \\
\text { incorrect } \\
\text { information }\end{array}$ & $\begin{array}{l}\text { Does not follow } \\
\text { up on } \\
\text { conversations }\end{array}$ & Unable to assess \\
\hline \multicolumn{7}{|c|}{ What is the child's native (first) language? } \\
\hline \multicolumn{7}{|c|}{ What is the language in which the assessment is being conducted? } \\
\hline \multicolumn{7}{|c|}{$\begin{array}{l}\text { Does the child speak/understand any languages other than his/her } \\
\text { native (first) language? }\end{array}$} \\
\hline \multicolumn{7}{|c|}{ How often were the following behaviours in the child during the assessment? } \\
\hline 31 & Positive Affect & \multicolumn{2}{|l|}{ Never or rarely } & Some of the time & \multicolumn{2}{|c|}{ Most of the time } \\
\hline 32 & Exploration & \multicolumn{2}{|l|}{ Never or rarely } & Some of the time & \multicolumn{2}{|c|}{ Most of the time } \\
\hline 33 & Ease of engagement & \multicolumn{2}{|l|}{ Never or rarely } & Some of the time & \multicolumn{2}{|c|}{ Most of the time } \\
\hline 34 & Cooperativeness & \multicolumn{2}{|l|}{ Never or rarely } & Some of the time & \multicolumn{2}{|c|}{ Most of the time } \\
\hline 35 & Adaptability to change & \multicolumn{2}{|l|}{ Never or rarely } & Some of the time & \multicolumn{2}{|c|}{ Most of the time } \\
\hline 36 & Distractibility & \multirow{2}{*}{$\begin{array}{l}\text { Never or rarely } \\
\text { Never or rarely }\end{array}$} & \multicolumn{2}{|c|}{ Some of the time } & Most of the & ime \\
\hline 37 & Negative affect & & Some of & the time & Most of the & ime \\
\hline & ver Reported Child Behaviour Questionnaire & & & & & \\
\hline In & ons to caregiver: Please fill in this form to reflect your & ur child's behavi & if others $\mathrm{c}$ & rree & & \\
\hline 38 & Likes playing with other children & Not true & Sometin & es true & Often true & \\
\hline 39 & Can't concentrate, can't pay attention for long & Not true & Sometin & es true & Often true & \\
\hline 40 & Can't sit still, restless or hyperactive & Not true & Sometin & es true & Often true & \\
\hline 41 & Disturbed by any change in routine & Not true & Sometin & les true & Often true & \\
\hline 42 & Nervous movements or twitching & Not true & Sometin & les true & Often true & \\
\hline 43 & Shows panic for no good reason & Not true & Sometin & es true & Often true & \\
\hline 44 & Poorly coordinated or clumsy & Not true & Sometin & es true & Often true & \\
\hline 45 & Quickly shifts from one activity to another & Not true & Sometin & es true & Often true & \\
\hline 46 & Rapid shifts between sadness and excitement & Not true & Sometin & les true & Often true & \\
\hline 47 & Sudden changes in mood or feelings & Not true & Sometin & les true & Often true & \\
\hline 48 & Sulks a lot & Not true & Sometin & les true & Often true & \\
\hline
\end{tabular}


Johanna Slim et al.

\begin{tabular}{|l|l|l|l|}
\hline 49 & Upset by new people or situations & Not true & Sometimes true \\
\hline 50 & Wanders away & Not true & Sometimes true \\
\hline 51 & Whining & Not true & Sometimes true \\
\hline 52 & Worries & Not true & Sometimes true \\
\hline 53 & Responds well to affection & Not true & Often true \\
\hline \multicolumn{2}{|c|}{ END } & Often true \\
\hline
\end{tabular}




\section{S3 INTER-NDA assessment form - for child 2 in a group}

\section{Child 2 - GROUP ASSESSMENT}

\section{Name:}

Study Number:

Assessor:

Scorer:

\begin{tabular}{|c|c|c|c|c|c|c|}
\hline \multicolumn{7}{|c|}{ rim } \\
\hline 2 & $\begin{array}{l}\text { Names } 4 \text { colours when asked to do so (trials }=1 \text {, } \\
\text { demonstration }=O \text { ) }\end{array}$ & Names 4 colours & Names 3 colours & $\begin{array}{l}\text { Names } 1 \text { or } 2 \\
\text { colours }\end{array}$ & $\begin{array}{l}\text { Does not name } \\
\text { any colour }\end{array}$ & Unable to assess \\
\hline 5 & $\begin{array}{l}\text { Puts the spoon in the cup when asked to do so (trials }=5 \text {, } \\
\text { demonstration }=O \text { ) }\end{array}$ & $\begin{array}{l}\text { Puts the spoon in } \\
\text { cup in } \leq 3 \text { trials }\end{array}$ & $\begin{array}{l}\text { Puts the spoon in } \\
\text { cup in } 4-5 \text { trials }\end{array}$ & $\begin{array}{l}\text { Takes the spoon or } \\
\text { the cup but does } \\
\text { not complete action }\end{array}$ & No attempt & Unable to assess \\
\hline 3 & $\begin{array}{l}\text { Matches } 3 \text { cubes of same colours when requested to do so } \\
\text { (trials }=1 \text {, demonstration }=1 \text { of one colour) }\end{array}$ & $\begin{array}{l}\text { Matches } 3 \\
\text { colours }\end{array}$ & Matches 2 colours & Matches 1 colour & $\begin{array}{l}\text { Does not match } \\
\text { any colour }\end{array}$ & Unable to assess \\
\hline 8 & $\begin{array}{l}\text { Points correctly when asked "Where is the door/entrance to } \\
\text { the room?" (trials }=5 \text {, demonstration }=O \text { ) }\end{array}$ & $\begin{array}{l}\text { Identifies door } \\
\text { correctly in } \leq 3 \\
\text { trials }\end{array}$ & $\begin{array}{l}\text { Identifies door } \\
\text { correctly in 4-5 } \\
\text { trials }\end{array}$ & $\begin{array}{l}\text { Attempts, but does } \\
\text { not identify door }\end{array}$ & No attempt & Unable to assess \\
\hline 1 & Builds a tower of 5 cubes (trials $=3$, demonstration $=3$ ) & 5 cubes & 3-4 cubes & 2 cubes & No attempt & Unable to assess \\
\hline 4 & $\begin{array}{l}\text { Hands the examiner one cube when asked to do so (Examiner } \\
\text { says "Please give me one cube" \& keeps palm open for } 5 \\
\text { seconds after child has handed over } 1 \text { cube) (trials }=1 \text {, } \\
\text { demonstration }=O \text { ) }\end{array}$ & $\begin{array}{l}\text { Hands only one } \\
\text { block within } 5 \\
\text { seconds }\end{array}$ & $\begin{array}{l}\text { Hands only one } \\
\text { block in more than } \\
5 \text { seconds }\end{array}$ & $\begin{array}{l}\text { Hands two or more } \\
\text { blocks }\end{array}$ & $\begin{array}{l}\text { Does not hand } \\
\text { any block / No } \\
\text { attempt }\end{array}$ & Unable to assess \\
\hline 7 & $\begin{array}{l}\text { Matches shapes on rotated board (trials }=5 \text {, demonstration } \\
=\text { partial }- \text { removal only) }\end{array}$ & $\begin{array}{l}\text { All shapes in } \leq 3 \\
\text { trials }\end{array}$ & $\begin{array}{l}\text { All shapes with } \\
\text { repeated } \\
\text { demonstration i.e. } \\
4-5 \text { trials }\end{array}$ & $\begin{array}{l}\text { One or two shapes } \\
\text { in } 4-5 \text { trials }\end{array}$ & No attempt & Unable to assess \\
\hline 11 & $\begin{array}{l}\text { Looks towards an object located across the room when pointed } \\
\text { at by the examiner }(\text { trials }=5)\end{array}$ & $\begin{array}{l}\text { Looks or points at } \\
\text { object in } \leq 3 \text { trials }\end{array}$ & $\begin{array}{l}\text { Looks or points at } \\
\text { object in } 4-5 \text { trials }\end{array}$ & $\begin{array}{l}\text { Looks at the wrong } \\
\text { object, or attempts } \\
\text { but cannot identify } \\
\text { object }\end{array}$ & No attempt & Unable to assess \\
\hline 9 & $\begin{array}{l}\text { Puts a raisin precisely inside a small opening in a bottle } \\
\text { (trials }=1 \text {, demonstration }=1 \text {; test both hands) }\end{array}$ & $\begin{array}{l}\text { Precise release of } \\
\text { raisin into bottle } \\
\text { with each hand }\end{array}$ & $\begin{array}{l}\text { Clumsy release, } \\
\text { raisin falls out of } \\
\text { bottle with one or } \\
\text { more hand }\end{array}$ & $\begin{array}{l}\text { Attempts but } \\
\text { unsuccessful } \\
\text { release with one or } \\
\text { more hand }\end{array}$ & No attempt & Unable to assess \\
\hline 15 & $\begin{array}{l}\text { Imitates straight horizontal scribble (trials }=5 \text {, } \\
\text { demonstration }=5 \text { ) }\end{array}$ & $\leq 3$ trials & $\begin{array}{l}4-5 \text { trials; with } \\
\text { difficulty }\end{array}$ & $\begin{array}{l}\text { Attempts (hold } \\
\text { crayon) }\end{array}$ & $\begin{array}{l}\text { Cannot hold } \\
\text { crayon }\end{array}$ & Unable to assess \\
\hline
\end{tabular}




\begin{tabular}{|c|c|c|c|c|c|c|}
\hline 6 & $\begin{array}{l}\text { Matches shapes on board (trials }=5 \text {, demonstration }=\text { partial - } \\
\text { removal only) }\end{array}$ & $\begin{array}{l}\text { All shapes in } \leq 3 \\
\text { trials }\end{array}$ & $\begin{array}{l}\text { All shapes with } \\
\text { repeated } \\
\text { demonstration i.e. } \\
4-5 \text { trials }\end{array}$ & $\begin{array}{l}\text { One or two shapes } \\
\text { in } 4-5 \text { trials }\end{array}$ & No attempt & Unable to assess \\
\hline 10 & $\begin{array}{l}\text { Drinks water from cup/bottle/sippy cup when placed in front } \\
\text { of child (trials=1, maternal recall if observation not possible) }\end{array}$ & $\begin{array}{l}\text { Drinks water } \\
\text { from cup/sippy } \\
\text { cup without } \\
\text { spilling }\end{array}$ & $\begin{array}{l}\text { Drinks clumsily \& } \\
\text { spills }\end{array}$ & $\begin{array}{l}\text { Attempts but } \\
\text { unsuccessful }\end{array}$ & No attempt & Unable to assess \\
\hline 13 & $\begin{array}{l}\text { Able to make a cup of tea with the toy tea set when requested } \\
\text { by examiner (Examiner says “Can you make a cup of tea?") } \\
\text { (trials=2, demonstration=1 if not spontaneous on first } \\
\text { attempt) }\end{array}$ & $\begin{array}{l}\text { Spontaneously, } \\
\text { with pouring } \\
\text { motion }\end{array}$ & $\begin{array}{l}\text { After } 1 \\
\text { demonstration }\end{array}$ & $\begin{array}{l}\text { Partial attempt } \\
\text { after } 1 \\
\text { demonstration }\end{array}$ & No attempt & Unable to assess \\
\hline 17 & $\begin{array}{l}\text { Correctly identifies object groups using plurals (concurrent } \\
\text { observation) }\end{array}$ & Uses 5 plurals & Uses 3-4 plurals & Uses 1-2 plurals & $\begin{array}{l}\text { Does not use } \\
\text { any plurals }\end{array}$ & Unable to assess \\
\hline 14 & $\begin{array}{l}\text { Feeds doll when requested to (Examiner says "Can you give } \\
\text { the dolly some tea?") (trials=2, demonstration=1 if not } \\
\text { spontaneous on first attempt) }\end{array}$ & Spontaneously & $\begin{array}{l}\text { After } 1 \\
\text { demonstration }\end{array}$ & $\begin{array}{l}\text { Partial attempt } \\
\text { after } 1 \\
\text { demonstration }\end{array}$ & No attempt & Unable to assess \\
\hline 30 & $\begin{array}{l}\text { Combines word and gesture when asked (trials }=3, \text { Do Not } \\
\text { demonstrate, use different example if mother says child does } \\
\text { not know the one you are asking) }\end{array}$ & $\begin{array}{l}\text { Combines word } \\
\text { and gesture } \\
\text { completely and } \\
\text { appropriately }\end{array}$ & $\begin{array}{l}\text { Combines word } \\
\text { and gesture } \\
\text { completely but } \\
\text { inappropriately }\end{array}$ & $\begin{array}{l}\text { Combines word } \\
\text { and gesture } \\
\text { incompletely and } \\
\text { inappropriately }\end{array}$ & None & Unable to assess \\
\hline 12 & $\begin{array}{l}\text { Pretends to drink from a toy cup when placed in front of } \\
\text { him/her (trials=2, demonstration=1 if not spontaneous on } \\
\text { first attempt) }\end{array}$ & Spontaneously & $\begin{array}{l}\text { After } 1 \\
\text { demonstration }\end{array}$ & $\begin{array}{l}\text { Partial attempt } \\
\text { after } 1 \\
\text { demonstration }\end{array}$ & No attempt & Unable to assess \\
\hline 16 & $\begin{array}{l}\text { Identifies glitter bracelet under correct washcloth (trials }=5 \text {, } \\
\text { demonstration }=0 \text {, test both sides) }\end{array}$ & $\begin{array}{l}\text { Finds bracelet } \\
\text { correctly in } \leq 2 \\
\text { trails on both } \\
\text { sides }\end{array}$ & $\begin{array}{l}\text { Find bracelet } \\
\text { correctly in } 3 \text { trials } \\
\text { or on one side } \\
\text { only }\end{array}$ & $\begin{array}{l}\text { Find bracelet } \\
\text { correctly in } 4-5 \\
\text { trials or on one side } \\
\text { only }\end{array}$ & $\begin{array}{l}\text { Does not find } \\
\text { bracelet or no } \\
\text { attempt }\end{array}$ & Unable to assess \\
\hline 20 & $\begin{array}{l}\text { Throws a ball very near (trials }=1 \text {, demonstration }=1 \text {, test both } \\
\text { hands) }\end{array}$ & Good release & Unsteady release & Attempts & No attempt & Unable to assess \\
\hline 21 & Kicks ball (maternal recall) & $\begin{array}{l}\text { Kicks ball with } \\
\text { knee flexed }\end{array}$ & $\begin{array}{l}\text { Runs after ball \& } \\
\text { attempts kicking it }\end{array}$ & $\begin{array}{l}\text { Walks and touches } \\
\text { ball with foot }\end{array}$ & No attempt & Unable to assess \\
\hline 19 & Runs (maternal recall) & Runs steadily & Attempts & Walks only & $\begin{array}{l}\text { Walks with } \\
\text { support }\end{array}$ & Unable to assess \\
\hline 18 & Asks for toilet by gesture or verbally (maternal recall) & Always & Occasionally & $\begin{array}{l}\text { Partial (only for } \\
\text { bowel movement) }\end{array}$ & Never & Unable to assess \\
\hline 22 & $\begin{array}{l}\text { Climbs upstairs holding rail, } 2 \text { feet/stair or in adult fashion } \\
\text { (maternal recall) }\end{array}$ & $\begin{array}{l}\text { Climbs stairs } \\
\text { alone steadily }\end{array}$ & $\begin{array}{l}\text { Climb stairs alone } \\
\text { unsteadily }\end{array}$ & $\begin{array}{l}\text { Climbs stairs with } \\
\text { help (uses railing, } \\
\text { holds adult's hand) }\end{array}$ & No attempt & Unable to assess \\
\hline 23 & $\begin{array}{l}\text { Uses 2-4 syllable babble such as dada, mama but not } \\
\text { specifically to anything or any person (concurrent } \\
\text { observation) }\end{array}$ & Spontaneously & Mimics & $\begin{array}{l}1 \text { syllable babble } \\
\text { e.g. ba, ma, da }\end{array}$ & None & Unable to assess \\
\hline 24 & Use two words together (concurrent observation) & $\begin{array}{l}\text { Two words, } \\
\text { appropriate use }\end{array}$ & $\begin{array}{l}\text { Two words, } \\
\text { inappropriate use }\end{array}$ & $\begin{array}{l}\text { One word, } \\
\text { appropriate use }\end{array}$ & No attempt & Unable to assess \\
\hline
\end{tabular}


Int. J. Growth Dev. 2018, 2: 11-33

http://igdjournal.com/

\begin{tabular}{|c|c|c|c|c|c|c|}
\hline 25 & $\begin{array}{l}\text { Indicates by gesture to say no (maternal recall if not observed } \\
\text { during assessment) }\end{array}$ & $\begin{array}{l}\text { Indicates verbally } \\
\text { or by definite } \\
\text { gesture all the } \\
\text { time }\end{array}$ & $\begin{array}{l}\text { Indicates verbally } \\
\text { or by definite } \\
\text { gesture some of } \\
\text { the time }\end{array}$ & $\begin{array}{l}\text { Attempts, but } \\
\text { incomplete } \\
\text { indication }\end{array}$ & No attempt & Unable to assess \\
\hline 26 & $\begin{array}{l}\text { Use of a pronoun e.g. me, my, she, he, it, I (concurrent } \\
\text { observation) }\end{array}$ & $\begin{array}{l}\geq 1 \text { pronoun in } \\
\text { correct context }\end{array}$ & $\begin{array}{l}\geq 1 \text { pronoun, } \\
\text { incorrect use }\end{array}$ & $\begin{array}{l}\text { Use of proper } \\
\text { names, but not } \\
\text { pronouns }\end{array}$ & No use & Unable to assess \\
\hline 27 & $\begin{array}{l}\text { How many words does the child use during the assessment } \\
\text { other than mama/dada (concurrent observation) }\end{array}$ & $\geq 8$ words & 6-7 words & $4-5$ words & $\leq 3$ words & Unable to assess \\
\hline 28 & $\begin{array}{l}\text { How many sentences of } 3 \text { words or more does the child use } \\
\text { during the assessment? (concurrent observation) }\end{array}$ & $\geq 2$ & 1 & $\begin{array}{l}\geq 1 \text { two word } \\
\text { utterance }\end{array}$ & None & Unable to assess \\
\hline 29 & $\begin{array}{l}\text { In how many instances does the child follow on a topic of } \\
\text { conversation providing new information? (concurrent } \\
\text { observation) }\end{array}$ & $\begin{array}{l}\text { At least one, } \\
\text { using } \geq 2 \text { words, } \\
\text { proving correct } \\
\text { information }\end{array}$ & $\begin{array}{l}\text { At least one, uses } \\
\text { single words, } \\
\text { provides correct } \\
\text { information }\end{array}$ & $\begin{array}{l}\text { Uses any number } \\
\text { of words, provides } \\
\text { incorrect } \\
\text { information }\end{array}$ & $\begin{array}{l}\text { Does not follow } \\
\text { up on } \\
\text { conversations }\end{array}$ & Unable to assess \\
\hline \multicolumn{7}{|c|}{ What is the child's native (first) language? } \\
\hline \multicolumn{7}{|c|}{ What is the language in which the assessment is being conducted? } \\
\hline \multicolumn{7}{|c|}{$\begin{array}{l}\text { Does the child speak/understand any languages other than his/her } \\
\text { native (first) language? }\end{array}$} \\
\hline \multicolumn{7}{|c|}{ How often were the following behaviours in the child during the assessment? } \\
\hline 31 & Positive Affect & \multicolumn{2}{|l|}{ Never or rarely } & Some of the time & \multicolumn{2}{|c|}{ Most of the time } \\
\hline 32 & Exploration & \multicolumn{2}{|l|}{ Never or rarely } & Some of the time & \multicolumn{2}{|c|}{ Most of the time } \\
\hline 33 & Ease of engagement & \multicolumn{2}{|l|}{ Never or rarely } & Some of the time & \multicolumn{2}{|c|}{ Most of the time } \\
\hline 34 & Cooperativeness & \multicolumn{2}{|l|}{ Never or rarely } & Some of the time & \multicolumn{2}{|c|}{ Most of the time } \\
\hline 35 & Adaptability to change & \multicolumn{2}{|l|}{ Never or rarely } & Some of the time & \multicolumn{2}{|c|}{ Most of the time } \\
\hline 36 & Distractibility & \multirow{2}{*}{ Never or rarely } & Some of & the time & Most of the & ime \\
\hline 37 & Negative affect & & Some of & the time & Most of the & ime \\
\hline CaI & iver Reported Child Behaviour Questionnaire & & & & & \\
\hline In & ons to caregiver: Please fill in this form $t$ & Ir child's behav & ers c & ree & & \\
\hline 38 & Likes playing with other children & Not true & Sometin & es true & Often true & \\
\hline 39 & Can't concentrate, can't pay attention for long & Not true & Sometin & es true & Often true & \\
\hline 40 & Can't sit still, restless or hyperactive & Not true & Sometin & es true & Often true & \\
\hline 41 & Disturbed by any change in routine & Not true & Sometin & es true & Often true & \\
\hline 42 & Nervous movements or twitching & Not true & Sometin & es true & Often true & \\
\hline 43 & Shows panic for no good reason & Not true & Sometin & es true & Often true & \\
\hline 44 & Poorly coordinated or clumsy & Not true & Sometin & es true & Often true & \\
\hline 45 & Quickly shifts from one activity to another & Not true & Sometin & es true & Often true & \\
\hline 46 & Rapid shifts between sadness and excitement & Not true & Sometin & es true & Often true & \\
\hline 47 & Sudden changes in mood or feelings & Not true & Sometin & es true & Often true & \\
\hline 48 & Sulks a lot & Not true & Sometin & es true & Often true & \\
\hline 49 & Upset by new people or situations & Not true & Sometin & es true & Often true & \\
\hline 50 & Wanders away & Not true & Sometin & es true & Often true & \\
\hline
\end{tabular}




\begin{tabular}{|l|l|l|l|l|}
\hline 51 & Whining & Not true & Sometimes true \\
\hline 52 & Worries & Not true & Sometimes true \\
\hline 53 & Responds well to affection & Not true & Sometimes true \\
\hline END
\end{tabular}

\section{S4 INTER-NDA assessment form - for child 3 in a group}

\section{Child 3 - GROUP ASSESSMENT}

\section{Name:}

Date:

Study Number:

Assessor:

Scorer:

\begin{tabular}{|c|c|c|c|c|c|c|}
\hline \multicolumn{7}{|c|}{ The INTERGROWTH-21 ${ }^{\text {st }}$ Neurodevelopment Assessment (INTER-NDA) } \\
\hline No. & Item & \multicolumn{5}{|c|}{ Observed performance } \\
\hline 3 & $\begin{array}{l}\text { Matches } 3 \text { cubes of same colours when requested to do so } \\
\text { (trials }=1 \text {, demonstration }=1 \text { of one colour) }\end{array}$ & $\begin{array}{l}\text { Matches } 3 \\
\text { colours }\end{array}$ & Matches 2 colours & Matches 1 colour & $\begin{array}{l}\text { Does not match } \\
\text { any colour }\end{array}$ & Unable to assess \\
\hline 8 & $\begin{array}{l}\text { Points correctly when asked “Where is the door/entrance to } \\
\text { the room?" (trials }=5 \text {, demonstration=O) }\end{array}$ & $\begin{array}{l}\text { Identifies door } \\
\text { correctly in } \leq 3 \\
\text { trials }\end{array}$ & $\begin{array}{l}\text { Identifies door } \\
\text { correctly in 4-5 } \\
\text { trials }\end{array}$ & $\begin{array}{l}\text { Attempts, but does } \\
\text { not identify door }\end{array}$ & No attempt & Unable to assess \\
\hline 1 & Builds a tower of 5 cubes (trials $=3$, demonstration $=3$ ) & 5 cubes & 3-4 cubes & 2 cubes & No attempt & Unable to assess \\
\hline 4 & $\begin{array}{l}\text { Hands the examiner one cube when asked to do so (Examiner } \\
\text { says "Please give me one cube" \& keeps palm open for } 5 \\
\text { seconds after child has handed over } 1 \text { cube) (trials }=1 \text {, } \\
\text { demonstration }=O \text { ) }\end{array}$ & $\begin{array}{l}\text { Hands only one } \\
\text { block within } 5 \\
\text { seconds }\end{array}$ & $\begin{array}{l}\text { Hands only one } \\
\text { block in more than } \\
5 \text { seconds }\end{array}$ & $\begin{array}{l}\text { Hands two or more } \\
\text { blocks }\end{array}$ & $\begin{array}{l}\text { Does not hand } \\
\text { any block / No } \\
\text { attempt }\end{array}$ & Unable to assess \\
\hline 2 & $\begin{array}{l}\text { Names } 4 \text { colours when asked to do so (trials }=1 \text {, } \\
\text { demonstration }=O \text { ) }\end{array}$ & Names 4 colours & Names 3 colours & $\begin{array}{l}\text { Names } 1 \text { or } 2 \\
\text { colours }\end{array}$ & $\begin{array}{l}\text { Does not name } \\
\text { any colour }\end{array}$ & Unable to assess \\
\hline 5 & $\begin{array}{l}\text { Puts the spoon in the cup when asked to do so (trials }=5 \text {, } \\
\text { demonstration }=O \text { ) }\end{array}$ & $\begin{array}{l}\text { Puts the spoon in } \\
\text { cup in } \leq 3 \text { trials }\end{array}$ & $\begin{array}{l}\text { Puts the spoon in } \\
\text { cup in } 4-5 \text { trials }\end{array}$ & $\begin{array}{l}\text { Takes the spoon or } \\
\text { the cup but does } \\
\text { not complete action }\end{array}$ & No attempt & Unable to assess \\
\hline 9 & $\begin{array}{l}\text { Puts a raisin precisely inside a small opening in a bottle } \\
\text { (trials }=1 \text {, demonstration }=1 \text {; test both hands) }\end{array}$ & $\begin{array}{l}\text { Precise release of } \\
\text { raisin into bottle } \\
\text { with each hand }\end{array}$ & $\begin{array}{l}\text { Clumsy release, } \\
\text { raisin falls out of } \\
\text { bottle with one or } \\
\text { more hand }\end{array}$ & $\begin{array}{l}\text { Attempts but } \\
\text { unsuccessful } \\
\text { release with one or } \\
\text { more hand }\end{array}$ & No attempt & Unable to assess \\
\hline 15 & $\begin{array}{l}\text { Imitates straight horizontal scribble (trials }=5 \text {, } \\
\text { demonstration }=5 \text { ) }\end{array}$ & $\leq 3$ trials & $\begin{array}{l}4-5 \text { trials; with } \\
\text { difficulty }\end{array}$ & $\begin{array}{l}\text { Attempts (hold } \\
\text { crayon) }\end{array}$ & $\begin{array}{l}\text { Cannot hold } \\
\text { crayon }\end{array}$ & Unable to assess \\
\hline 6 & $\begin{array}{l}\text { Matches shapes on board (trials }=5 \text {, demonstration }=\text { partial }- \\
\text { removal only) }\end{array}$ & $\begin{array}{l}\text { All shapes in } \leq 3 \\
\text { trials }\end{array}$ & $\begin{array}{l}\text { All shapes with } \\
\text { repeated } \\
\text { demonstration i.e. } \\
4-5 \text { trials }\end{array}$ & $\begin{array}{l}\text { One or two shapes } \\
\text { in } 4-5 \text { trials }\end{array}$ & No attempt & Unable to assess \\
\hline
\end{tabular}


Int. J. Growth Dev. 2018, 2: 11-33

http://igdjournal.com/

\begin{tabular}{|c|c|c|c|c|c|c|}
\hline 10 & $\begin{array}{l}\text { Drinks water from cup/bottle/sippy cup when placed in front } \\
\text { of child (trials=1, maternal recall if observation not possible) }\end{array}$ & $\begin{array}{l}\text { Drinks water } \\
\text { from cup/sippy } \\
\text { cup without } \\
\text { spilling }\end{array}$ & $\begin{array}{l}\text { Drinks clumsily \& } \\
\text { spills }\end{array}$ & $\begin{array}{l}\text { Attempts but } \\
\text { unsuccessful }\end{array}$ & No attempt & Unable to assess \\
\hline 7 & $\begin{array}{l}\text { Matches shapes on rotated board (trials }=5 \text {, demonstration } \\
=\text { partial }- \text { removal only) }\end{array}$ & $\begin{array}{l}\text { All shapes in } \leq 3 \\
\text { trials }\end{array}$ & $\begin{array}{l}\text { All shapes with } \\
\text { repeated } \\
\text { demonstration i.e. } \\
4-5 \text { trials }\end{array}$ & $\begin{array}{l}\text { One or two shapes } \\
\text { in } 4-5 \text { trials }\end{array}$ & No attempt & Unable to assess \\
\hline 11 & $\begin{array}{l}\text { Looks towards an object located across the room when pointed } \\
\text { at by the examiner (trials }=5 \text { ) }\end{array}$ & $\begin{array}{l}\text { Looks or points at } \\
\text { object in } \leq 3 \text { trials }\end{array}$ & $\begin{array}{l}\text { Looks or points at } \\
\text { object in } 4-5 \text { trials }\end{array}$ & $\begin{array}{l}\text { Looks at the wrong } \\
\text { object, or attempts } \\
\text { but cannot identify } \\
\text { object }\end{array}$ & No attempt & Unable to assess \\
\hline 14 & $\begin{array}{l}\text { Feeds doll when requested to (Examiner says "Can you give } \\
\text { the dolly some tea?") (trials=2, demonstration=1 if not } \\
\text { spontaneous on first attempt) }\end{array}$ & Spontaneously & $\begin{array}{l}\text { After } 1 \\
\text { demonstration }\end{array}$ & $\begin{array}{l}\text { Partial attempt } \\
\text { after } 1 \\
\text { demonstration }\end{array}$ & No attempt & Unable to assess \\
\hline 30 & $\begin{array}{l}\text { Combines word and gesture when asked (trials }=3, \text { Do Not } \\
\text { demonstrate, use different example if mother says child does } \\
\text { not know the one you are asking) }\end{array}$ & $\begin{array}{l}\text { Combines word } \\
\text { and gesture } \\
\text { completely and } \\
\text { appropriately }\end{array}$ & $\begin{array}{l}\text { Combines word } \\
\text { and gesture } \\
\text { completely but } \\
\text { inappropriately }\end{array}$ & $\begin{array}{l}\text { Combines word } \\
\text { and gesture } \\
\text { incompletely and } \\
\text { inappropriately }\end{array}$ & None & Unable to assess \\
\hline 12 & $\begin{array}{l}\text { Pretends to drink from a toy cup when placed in front of } \\
\text { him/her (trials=2, demonstration=1 if not spontaneous on } \\
\text { first attempt) }\end{array}$ & Spontaneously & $\begin{array}{l}\text { After } 1 \\
\text { demonstration }\end{array}$ & $\begin{array}{l}\text { Partial attempt } \\
\text { after } 1 \\
\text { demonstration }\end{array}$ & No attempt & Unable to assess \\
\hline 16 & $\begin{array}{l}\text { Identifies glitter bracelet under correct washcloth (trials }=5 \text {, } \\
\text { demonstration }=0 \text {, test both sides) }\end{array}$ & $\begin{array}{l}\text { Finds bracelet } \\
\text { correctly in } \leq 2 \\
\text { trails on both } \\
\text { sides }\end{array}$ & $\begin{array}{l}\text { Find bracelet } \\
\text { correctly in } 3 \text { trials } \\
\text { or on one side } \\
\text { only }\end{array}$ & $\begin{array}{l}\text { Find bracelet } \\
\text { correctly in } 4-5 \\
\text { trials or on one side } \\
\text { only }\end{array}$ & $\begin{array}{l}\text { Does not find } \\
\text { bracelet or no } \\
\text { attempt }\end{array}$ & Unable to assess \\
\hline 13 & $\begin{array}{l}\text { Able to make a cup of tea with the toy tea set when requested } \\
\text { by examiner (Examiner says "Can you make a cup of tea?") } \\
\text { (trials=2, demonstration=1 if not spontaneous on first } \\
\text { attempt) }\end{array}$ & $\begin{array}{l}\text { Spontaneously, } \\
\text { with pouring } \\
\text { motion }\end{array}$ & $\begin{array}{l}\text { After } 1 \\
\text { demonstration }\end{array}$ & $\begin{array}{l}\text { Partial attempt } \\
\text { after } 1 \\
\text { demonstration }\end{array}$ & No attempt & Unable to assess \\
\hline 17 & $\begin{array}{l}\text { Correctly identifies object groups using plurals (concurrent } \\
\text { observation) }\end{array}$ & Uses 5 plurals & Uses 3-4 plurals & Uses 1-2 plurals & $\begin{array}{l}\text { Does not use } \\
\text { any plurals }\end{array}$ & Unable to assess \\
\hline 21 & Kicks ball (maternal recall) & $\begin{array}{l}\text { Kicks ball with } \\
\text { knee flexed }\end{array}$ & $\begin{array}{l}\text { Runs after ball \& } \\
\text { attempts kicking it }\end{array}$ & $\begin{array}{l}\text { Walks and touches } \\
\text { ball with foot }\end{array}$ & No attempt & Unable to assess \\
\hline 19 & Runs (maternal recall) & Runs steadily & Attempts & Walks only & $\begin{array}{l}\text { Walks with } \\
\text { support }\end{array}$ & Unable to assess \\
\hline 20 & $\begin{array}{l}\text { Throws a ball very near (trials }=1 \text {, demonstration }=1 \text {, test both } \\
\text { hands) }\end{array}$ & Good release & Unsteady release & Attempts & No attempt & Unable to assess \\
\hline 18 & Asks for toilet by gesture or verbally (maternal recall) & Always & Occasionally & $\begin{array}{l}\text { Partial (only for } \\
\text { bowel movement) }\end{array}$ & Never & Unable to assess \\
\hline 22 & $\begin{array}{l}\text { Climbs upstairs holding rail, } 2 \text { feet/stair or in adult fashion } \\
\text { (maternal recall) }\end{array}$ & $\begin{array}{l}\text { Climbs stairs } \\
\text { alone steadily }\end{array}$ & $\begin{array}{l}\text { Climb stairs alone } \\
\text { unsteadily }\end{array}$ & $\begin{array}{l}\text { Climbs stairs with } \\
\text { help (uses railing, } \\
\text { holds adult's hand) }\end{array}$ & No attempt & Unable to assess \\
\hline
\end{tabular}




\begin{tabular}{|c|c|c|c|c|c|c|}
\hline 23 & $\begin{array}{l}\text { Uses 2-4 syllable babble such as dada, mama but not } \\
\text { specifically to anything or any person (concurrent } \\
\text { observation) }\end{array}$ & Spontaneously & Mimics & $\begin{array}{l}1 \text { syllable babble } \\
\text { e.g. ba, ma, da }\end{array}$ & None & Unable to assess \\
\hline 24 & Use two words together (concurrent observation) & $\begin{array}{l}\text { Two words, } \\
\text { appropriate use }\end{array}$ & $\begin{array}{l}\text { Two words, } \\
\text { inappropriate use }\end{array}$ & $\begin{array}{l}\text { One word, } \\
\text { appropriate use }\end{array}$ & No attempt & Unable to assess \\
\hline 25 & $\begin{array}{l}\text { Indicates by gesture to say no (maternal recall if not observed } \\
\text { during assessment) }\end{array}$ & $\begin{array}{l}\text { Indicates verbally } \\
\text { or by definite } \\
\text { gesture all the } \\
\text { time }\end{array}$ & $\begin{array}{l}\text { Indicates verbally } \\
\text { or by definite } \\
\text { gesture some of } \\
\text { the time }\end{array}$ & $\begin{array}{l}\text { Attempts, but } \\
\text { incomplete } \\
\text { indication }\end{array}$ & No attempt & Unable to assess \\
\hline 26 & $\begin{array}{l}\text { Use of a pronoun e.g. me, my, she, he, it, I (concurrent } \\
\text { observation) }\end{array}$ & $\begin{array}{l}\geq 1 \text { pronoun in } \\
\text { correct context }\end{array}$ & $\begin{array}{l}\geq 1 \text { pronoun, } \\
\text { incorrect use }\end{array}$ & $\begin{array}{l}\text { Use of proper } \\
\text { names, but not } \\
\text { pronouns }\end{array}$ & No use & Unable to assess \\
\hline 27 & $\begin{array}{l}\text { How many words does the child use during the assessment } \\
\text { other than mama/dada (concurrent observation) }\end{array}$ & $\geq 8$ words & 6-7 words & $4-5$ words & $\leq 3$ words & Unable to assess \\
\hline 28 & $\begin{array}{l}\text { How many sentences of } 3 \text { words or more does the child use } \\
\text { during the assessment? (concurrent observation) }\end{array}$ & $\geq 2$ & 1 & $\begin{array}{l}\geq 1 \text { two word } \\
\text { utterance }\end{array}$ & None & Unable to assess \\
\hline 29 & $\begin{array}{l}\text { In how many instances does the child follow on a topic of } \\
\text { conversation providing new information? (concurrent } \\
\text { observation) }\end{array}$ & $\begin{array}{l}\text { At least one, } \\
\text { using } \geq 2 \text { words, } \\
\text { proving correct } \\
\text { information }\end{array}$ & $\begin{array}{l}\text { At least one, uses } \\
\text { single words, } \\
\text { provides correct } \\
\text { information }\end{array}$ & $\begin{array}{l}\text { Uses any number } \\
\text { of words, provides } \\
\text { incorrect } \\
\text { information }\end{array}$ & $\begin{array}{l}\text { Does not follow } \\
\text { up on } \\
\text { conversations }\end{array}$ & Unable to assess \\
\hline \multicolumn{7}{|c|}{ What is the child's native (first) language? } \\
\hline \multicolumn{7}{|c|}{ What is the language in which the assessment is being conducted? } \\
\hline \multicolumn{7}{|c|}{$\begin{array}{l}\text { Does the child speak/understand any languages other than his/her } \\
\text { native (first) language? }\end{array}$} \\
\hline \multicolumn{7}{|c|}{ How often were the following behaviours in the child during the assessment? } \\
\hline 31 & Positive Affect & \multicolumn{2}{|l|}{ Never or rarely } & Some of the time & \multicolumn{2}{|c|}{ Most of the time } \\
\hline 32 & Exploration & \multicolumn{2}{|l|}{ Never or rarely } & Some of the time & \multicolumn{2}{|c|}{ Most of the time } \\
\hline 33 & Ease of engagement & \multicolumn{2}{|l|}{ Never or rarely } & Some of the time & \multicolumn{2}{|c|}{ Most of the time } \\
\hline 34 & Cooperativeness & \multicolumn{2}{|l|}{ Never or rarely } & Some of the time & \multicolumn{2}{|c|}{ Most of the time } \\
\hline 35 & Adaptability to change & \multicolumn{2}{|l|}{ Never or rarely } & Some of the time & Most of the & ime \\
\hline 36 & Distractibility & Never or rarely & Some of & the time & Most of the & ime \\
\hline & Negative affect & Never or rarely & Some of & the time & Most of the & ime \\
\hline & ver Reported Child Behaviour Questionnaire & & & & & \\
\hline & ns to caregiver: Please fill in this form to reflect your view & r child's behavi & ven if others do & gree & & \\
\hline 38 & Likes playing with other children & Not true & Sometin & es true & Often true & \\
\hline 39 & Can't concentrate, can't pay attention for long & Not true & Sometin & es true & Often true & \\
\hline 40 & Can't sit still, restless or hyperactive & Not true & Sometin & es true & Often true & \\
\hline 41 & Disturbed by any change in routine & Not true & Sometin & es true & Often true & \\
\hline 42 & Nervous movements or twitching & Not true & Sometin & es true & Often true & \\
\hline 43 & Shows panic for no good reason & Not true & Sometin & es true & Often true & \\
\hline 44 & Poorly coordinated or clumsy & Not true & Sometin & es true & Often true & \\
\hline
\end{tabular}




\begin{tabular}{|l|l|l|l|}
\hline 45 & Quickly shifts from one activity to another & Not true & Sometimes true \\
\hline 46 & Rapid shifts between sadness and excitement & Not true & Often true \\
\hline 47 & Sudden changes in mood or feelings & Not true & Often true \\
\hline 48 & Sulks a lot & Not true & Sometimes true \\
\hline 49 & Upset by new people or situations & Not true & Sometimes true \\
\hline 50 & Wanders away & Not true & Sometimes true \\
\hline 51 & Whining & Not true & Sometimes true \\
\hline 52 & Worries & Not true & Sometimes true \\
\hline 53 & Responds well to affection & Not true & Often true \\
\hline END & & Often true & Often true \\
\hline
\end{tabular}

S5 INTER-NDA assessment form - individual assessment

Name of child:

Name of assessor:

\begin{tabular}{|c|c|c|c|c|c|c|}
\hline No. & Item & \multicolumn{5}{|c|}{ Observed Performance } \\
\hline 1 & $\begin{array}{l}\text { Builds a tower of } 5 \text { cubes } \\
\text { (trials }=3 \text {, demonstration }=3 \text { ) }\end{array}$ & 5 cubes & 3-4 cubes & 2 cubes & No attempt & $\begin{array}{l}\text { Unable to } \\
\text { assess }\end{array}$ \\
\hline 2 & $\begin{array}{l}\text { Names } 4 \text { colours when asked to do so } \\
\text { (trials }=1 \text {, demonstration }=0 \text { ) }\end{array}$ & Names 4 colours & Names 3 colours & $\begin{array}{l}\text { Names } 1 \text { or } 2 \\
\text { colours }\end{array}$ & $\begin{array}{l}\text { Does not } \\
\text { name any } \\
\text { colour }\end{array}$ & $\begin{array}{l}\text { Unable to } \\
\text { assess }\end{array}$ \\
\hline 3 & $\begin{array}{l}\text { Matches } 3 \text { cubes of same colours when requested to } \\
\text { do so } \\
\text { (trials }=1 \text {, demonstration }=1 \text { of one colour) }\end{array}$ & Matches 3 colours & Matches 2 colours & Matches 1 colour & $\begin{array}{l}\text { Does not } \\
\text { match any } \\
\text { colour }\end{array}$ & $\begin{array}{l}\text { Unable to } \\
\text { assess }\end{array}$ \\
\hline 4 & $\begin{array}{l}\text { Hands the examiner one cube when asked to do so } \\
\text { (Examiner says "Please give me one cube" \& keeps } \\
\text { palm open for } 5 \text { seconds after child has handed over } \\
\text { 1 cube) } \\
\text { (trials }=1 \text {, demonstration }=0 \text { ) }\end{array}$ & $\begin{array}{l}\text { Hands only one } \\
\text { block within } 5 \\
\text { seconds }\end{array}$ & $\begin{array}{l}\text { Hands only one } \\
\text { block in more than } \\
5 \text { seconds }\end{array}$ & $\begin{array}{l}\text { Hands two or more } \\
\text { blocks }\end{array}$ & $\begin{array}{l}\text { Does not } \\
\text { hand any } \\
\text { block / No } \\
\text { attempt }\end{array}$ & $\begin{array}{l}\text { Unable to } \\
\text { assess }\end{array}$ \\
\hline 5 & $\begin{array}{l}\text { Puts the spoon in the cup when asked to do so } \\
\text { (trials }=5 \text {, demonstration }=0 \text { ) }\end{array}$ & $\begin{array}{l}\text { Puts the spoon in } \\
\text { cup in } \leq 3 \text { trials }\end{array}$ & $\begin{array}{l}\text { Puts the spoon in } \\
\text { cup in } 4-5 \text { trials }\end{array}$ & $\begin{array}{l}\text { Takes the spoon or } \\
\text { the cup but does } \\
\text { not complete } \\
\text { action }\end{array}$ & No attempt & $\begin{array}{l}\text { Unable to } \\
\text { assess }\end{array}$ \\
\hline 6 & $\begin{array}{l}\text { Matches shapes on board } \\
\text { (trials }=5 \text {, demonstration=partial }- \text { removal only) }\end{array}$ & $\begin{array}{l}\text { All shapes in } \leq 3 \\
\text { trials }\end{array}$ & $\begin{array}{l}\text { All shapes with } \\
\text { repeated } \\
\text { demonstration i.e. } \\
4-5 \text { trials }\end{array}$ & $\begin{array}{l}\text { One or two shapes } \\
\text { in } 4-5 \text { trials }\end{array}$ & No attempt & $\begin{array}{l}\text { Unable to } \\
\text { assess }\end{array}$ \\
\hline
\end{tabular}




\begin{tabular}{|c|c|c|c|c|c|c|}
\hline 7 & $\begin{array}{l}\text { Matches shapes on rotated board } \\
\text { (trials }=5 \text {, demonstration }=\text { partial }- \text { removal only) }\end{array}$ & $\begin{array}{l}\text { All shapes in } \leq 3 \\
\text { trials }\end{array}$ & $\begin{array}{l}\text { All shapes with } \\
\text { repeated } \\
\text { demonstration i.e. } \\
\text { 4-5 trials }\end{array}$ & $\begin{array}{l}\text { One or two shapes } \\
\text { in } 4-5 \text { trials }\end{array}$ & No attempt & $\begin{array}{l}\text { Unable to } \\
\text { assess }\end{array}$ \\
\hline 8 & $\begin{array}{l}\text { Points correctly when asked "Where is the } \\
\text { door/entrance to the room?" } \\
\text { (trials }=5 \text {, demonstration }=O \text { ) }\end{array}$ & $\begin{array}{l}\text { Identifies door } \\
\text { correctly in } \leq 3 \\
\quad \text { trials }\end{array}$ & $\begin{array}{l}\text { Identifies door } \\
\text { correctly in } 4-5 \\
\quad \text { trials }\end{array}$ & $\begin{array}{l}\text { Attempts, but does } \\
\text { not identify door }\end{array}$ & No attempt & $\begin{array}{l}\text { Unable to } \\
\text { assess }\end{array}$ \\
\hline 9 & $\begin{array}{l}\text { Puts a raisin precisely inside a small opening in a } \\
\text { bottle } \\
\text { (trials }=1 \text {, demonstration }=1 \text {, test both hands) }\end{array}$ & $\begin{array}{l}\text { Precise release of } \\
\text { raisin into bottle } \\
\text { with each hand }\end{array}$ & $\begin{array}{l}\text { Clumsy release, } \\
\text { raisin falls out of } \\
\text { bottle with one or } \\
\text { more hand }\end{array}$ & $\begin{array}{l}\text { Attempts but } \\
\text { unsuccessful } \\
\text { release with one or } \\
\text { more hand }\end{array}$ & No attempt & $\begin{array}{l}\text { Unable to } \\
\text { assess }\end{array}$ \\
\hline 10 & $\begin{array}{l}\text { Drinks water from cup/bottle/sippy cup when } \\
\text { placed in front of child } \\
\text { (trials }=1 \text {, demonstration }=O \text {; maternal recall if observation } \\
\text { not possible) }\end{array}$ & $\begin{array}{l}\text { Drinks water from } \\
\text { cup/sippy cup } \\
\text { without spilling }\end{array}$ & $\begin{array}{l}\text { Drinks clumsily \& } \\
\text { spills }\end{array}$ & $\begin{array}{l}\text { Attempts but } \\
\text { unsuccessful }\end{array}$ & No attempt & $\begin{array}{l}\text { Unable to } \\
\text { assess }\end{array}$ \\
\hline 11 & $\begin{array}{l}\text { Looks towards an object located across the room } \\
\text { when pointed at by the examiner } \\
\text { (trials=5) }\end{array}$ & $\begin{array}{l}\text { Looks or points at } \\
\text { object in } \leq 3 \text { trials }\end{array}$ & $\begin{array}{l}\text { Looks or points at } \\
\text { object in } 4-5 \text { trials }\end{array}$ & $\begin{array}{c}\text { Looks at the wrong } \\
\text { object, or attempts } \\
\text { but cannot identify } \\
\text { object }\end{array}$ & No attempt & $\begin{array}{l}\text { Unable to } \\
\text { assess }\end{array}$ \\
\hline 12 & $\begin{array}{l}\text { Pretends to drink from a toy cup when placed in } \\
\text { front of him/her } \\
\text { (trials }=2 \text {, demonstration=1 if not spontaneous on first } \\
\text { attempt) }\end{array}$ & Spontaneously & $\begin{array}{c}\text { After } 1 \\
\text { demonstration }\end{array}$ & $\begin{array}{c}\text { Partial attempt } \\
\text { after } 1 \\
\text { demonstration }\end{array}$ & No attempt & $\begin{array}{l}\text { Unable to } \\
\text { assess }\end{array}$ \\
\hline 13 & $\begin{array}{l}\text { Able to make a cup of tea with the toy tea set when } \\
\text { requested by examiner (Examiner says "Can you } \\
\text { make a cup of tea?") } \\
\text { (trials=2, demonstration=1 if not spontaneous on first } \\
\text { attempt) }\end{array}$ & $\begin{array}{l}\text { Spontaneously, } \\
\text { with pouring } \\
\text { motion }\end{array}$ & $\begin{array}{c}\text { After } 1 \\
\text { demonstration }\end{array}$ & $\begin{array}{l}\text { Partial attempt } \\
\quad \text { after } 1 \\
\text { demonstration }\end{array}$ & No attempt & $\begin{array}{l}\text { Unable to } \\
\text { assess }\end{array}$ \\
\hline 14 & $\begin{array}{l}\text { Feeds doll when requested to (Examiner says "Can } \\
\text { you give the dolly some tea?") } \\
\text { (trials=2, demonstration=1 if not spontaneous on first } \\
\text { attempt) }\end{array}$ & Spontaneously & $\begin{array}{c}\text { After } 1 \\
\text { demonstration }\end{array}$ & $\begin{array}{c}\text { Partial attempt } \\
\text { after } 1 \\
\text { demonstration }\end{array}$ & No attempt & $\begin{array}{l}\text { Unable to } \\
\text { assess }\end{array}$ \\
\hline 15 & $\begin{array}{l}\text { Imitates straight horizontal scribble } \\
(\text { trials }=5 \text {, demonstration }=5)\end{array}$ & $\leq 3$ trials & $\begin{array}{l}\text { 4-5 trials; with } \\
\text { difficulty }\end{array}$ & $\begin{array}{l}\text { Attempts (hold } \\
\text { crayon) }\end{array}$ & $\begin{array}{l}\text { Cannot hold } \\
\text { crayon }\end{array}$ & $\begin{array}{l}\text { Unable to } \\
\text { assess }\end{array}$ \\
\hline 16 & $\begin{array}{l}\text { Identifies glitter bracelet under correct washcloth } \\
\text { (trials }=5 \text {, demonstration }=0 \text {, test both sides) }\end{array}$ & $\begin{array}{l}\text { Finds bracelet } \\
\text { correctly in } \leq 2 \\
\text { trails on both sides }\end{array}$ & $\begin{array}{l}\text { Find bracelet } \\
\text { correctly in } 3 \text { trials } \\
\text { or on one side only }\end{array}$ & $\begin{array}{l}\text { Find bracelet } \\
\text { correctly in } 4-5 \\
\text { trials or on one } \\
\quad \text { side only }\end{array}$ & $\begin{array}{l}\text { Does not find } \\
\text { bracelet or no } \\
\text { attempt }\end{array}$ & $\begin{array}{l}\text { Unable to } \\
\text { assess }\end{array}$ \\
\hline
\end{tabular}




\begin{tabular}{|c|c|c|c|c|c|c|}
\hline 17 & $\begin{array}{l}\text { Correctly identifies object groups using plurals } \\
\text { (concurrent observation) }\end{array}$ & Uses 5 plurals & Uses 3-4 plurals & Uses 1-2 plurals & $\begin{array}{l}\text { Does not use } \\
\text { any plurals }\end{array}$ & $\begin{array}{c}\begin{array}{c}\text { Unable to } \\
\text { assess }\end{array} \\
\end{array}$ \\
\hline 18 & $\begin{array}{l}\text { Asks for toilet by gesture or verbally } \\
\text { (maternal recall) }\end{array}$ & Always & Occasionally & $\begin{array}{l}\text { Partial (only for } \\
\text { bowel movement) }\end{array}$ & Never & $\begin{array}{l}\text { Unable to } \\
\text { assess }\end{array}$ \\
\hline 19 & $\begin{array}{l}\text { Runs } \\
\text { (maternal recall) }\end{array}$ & Runs steadily & Attempts & Walks only & $\begin{array}{l}\text { Walks with } \\
\text { support }\end{array}$ & $\begin{array}{l}\text { Unable to } \\
\text { assess }\end{array}$ \\
\hline 20 & $\begin{array}{l}\text { Throws a ball very near } \\
\text { (trials=1, demonstration }=1 \text {; test both hands) }\end{array}$ & Good release & Unsteady release & Attempts & No attempt & $\begin{array}{l}\text { Unable to } \\
\text { assess }\end{array}$ \\
\hline 21 & $\begin{array}{l}\text { Kicks ball } \\
\text { (maternal recall) }\end{array}$ & $\begin{array}{l}\text { Kicks ball with knee } \\
\text { flexed }\end{array}$ & $\begin{array}{l}\text { Runs after ball \& } \\
\text { attempts kicking it }\end{array}$ & $\begin{array}{l}\text { Walks and touches } \\
\text { ball with foot }\end{array}$ & No attempt & $\begin{array}{l}\text { Unable to } \\
\text { assess }\end{array}$ \\
\hline 22 & $\begin{array}{l}\text { Climbs upstairs holding rail, } 2 \text { feet/stair or in adult } \\
\text { fashion } \\
\text { (maternal recall) }\end{array}$ & $\begin{array}{l}\text { Climbs stairs alone } \\
\text { steadily }\end{array}$ & $\begin{array}{l}\text { Climbs stairs alone } \\
\text { unsteadily }\end{array}$ & $\begin{array}{l}\text { Climbs stairs with } \\
\text { help (uses railing, } \\
\text { holds adult's hand) }\end{array}$ & No attempt & $\begin{array}{l}\text { Unable to } \\
\text { assess }\end{array}$ \\
\hline 23 & $\begin{array}{l}\text { Uses 2-4 syllable babble such as dada, mama but not } \\
\text { specifically to anything or any person } \\
\text { (concurrent observation) }\end{array}$ & Spontaneously & Mimics & $\begin{array}{l}1 \text { syllabe babble } \\
\text { e.g. ba, ma, da }\end{array}$ & None & $\begin{array}{l}\text { Unable to } \\
\text { assess }\end{array}$ \\
\hline 24 & $\begin{array}{l}\text { Use two words together } \\
\text { (concurrent observation) }\end{array}$ & $\begin{array}{l}\text { Two words, } \\
\text { appropriate use }\end{array}$ & $\begin{array}{l}\text { Two words, } \\
\text { inappropriate use }\end{array}$ & $\begin{array}{l}\text { One word, } \\
\text { appropriate use }\end{array}$ & No attempt & $\begin{array}{l}\text { Unable to } \\
\text { assess }\end{array}$ \\
\hline 25 & $\begin{array}{l}\text { Indicates by gesture to say no } \\
\text { (concurrent observation or maternal recall) }\end{array}$ & $\begin{array}{l}\text { Indicates verbally } \\
\text { or by definite } \\
\text { gesture all the time }\end{array}$ & $\begin{array}{l}\text { Indicates verbally } \\
\text { or by definite } \\
\text { gesture some of the } \\
\text { time }\end{array}$ & $\begin{array}{l}\text { Attempts, but } \\
\text { incomplete } \\
\text { indication }\end{array}$ & No attempt & $\begin{array}{l}\text { Unable to } \\
\text { assess }\end{array}$ \\
\hline 26 & $\begin{array}{l}\text { Use of a pronoun e.g. me, my, she, he, it, I } \\
\text { (concurrent observation) }\end{array}$ & $\begin{array}{l}\geq 1 \text { pronoun in } \\
\text { correct context }\end{array}$ & $\begin{array}{l}\geq 1 \text { pronoun, } \\
\text { incorrect use }\end{array}$ & $\begin{array}{l}\text { Use of proper } \\
\text { names but not } \\
\text { pronouns }\end{array}$ & No use & $\begin{array}{l}\text { Unable to } \\
\text { assess }\end{array}$ \\
\hline 27 & $\begin{array}{l}\text { How many words does the child use during the } \\
\text { assessment other than mama/dada } \\
\text { (concurrent observation) }\end{array}$ & $\geq 8$ words & $6-7$ words & 4-5 words & $\leq 3$ words & $\begin{array}{l}\text { Unable to } \\
\text { assess }\end{array}$ \\
\hline 28 & $\begin{array}{l}\text { How many sentences of } 3 \text { words or more does the } \\
\text { child use during the assessment? } \\
\text { (concurrent observation) }\end{array}$ & $\geq 2$ & 1 & $\begin{array}{l}\geq 1 \text { two word } \\
\text { utterance }\end{array}$ & None & $\begin{array}{l}\text { Unable to } \\
\text { assess }\end{array}$ \\
\hline 29 & $\begin{array}{l}\text { In how many instances does the child follow on a } \\
\text { topic of conversation providing new information? } \\
\text { (concurrent observation) }\end{array}$ & $\begin{array}{l}\text { At least one, using } \\
\geq 2 \text { words, proving } \\
\text { correct information }\end{array}$ & $\begin{array}{l}\text { At least one, uses } \\
\text { single words, } \\
\text { provides correct } \\
\text { information }\end{array}$ & $\begin{array}{l}\text { Uses any number } \\
\text { of words, provides } \\
\text { incorrect } \\
\text { information }\end{array}$ & $\begin{array}{l}\text { Does not } \\
\text { follow up on } \\
\text { conversations }\end{array}$ & $\begin{array}{l}\text { Unable to } \\
\text { assess }\end{array}$ \\
\hline
\end{tabular}




\begin{tabular}{|c|c|c|c|c|c|c|}
\hline 30 & $\begin{array}{l}\text { Combines word and gesture when asked } \\
\text { (Do not demonstrate, trials }=3 \text {, use different example if } \\
\text { mother says child does not know the one you are asking) }\end{array}$ & $\begin{array}{l}\text { Combines word } \\
\text { and gesture } \\
\text { completely and } \\
\text { appropriately }\end{array}$ & $\begin{array}{l}\text { Combines word } \\
\text { and gesture } \\
\text { completely but } \\
\text { inappropriately }\end{array}$ & $\begin{array}{l}\text { Combines word } \\
\text { and gesture } \\
\text { incompletely and } \\
\text { inappropriately }\end{array}$ & $\begin{array}{l}\text { Does not } \\
\text { combine a } \\
\text { word an } \\
\text { gesture }\end{array}$ & $\begin{array}{l}\text { Unable to } \\
\text { assess }\end{array}$ \\
\hline
\end{tabular}

What is the child's native (first) language?

What is the language in which the assessment is being conducted?

Does the child speak/understand any languages other than his/her native (first) language?

How often were the following behaviours in the child during the assessment?

\begin{tabular}{|c|c|c|c|c|}
\hline 31 & Positive Affect & Never or rarely & $\begin{array}{c}\text { Some of the } \\
\text { time }\end{array}$ & Most of the time \\
\hline 32 & Exploration & Never or rarely & $\begin{array}{c}\text { Some of the } \\
\text { time }\end{array}$ & Most of the time \\
\hline 33 & Ease of engagement & Never or rarely & $\begin{array}{c}\text { Some of the } \\
\text { time }\end{array}$ & Most of the time \\
\hline 34 & Cooperativeness & Never or rarely & $\begin{array}{c}\text { Some of the } \\
\text { time }\end{array}$ & Most of the time \\
\hline 35 & Adaptability to change & Never or rarely & $\begin{array}{c}\text { Some of the } \\
\text { time }\end{array}$ & Most of the time \\
\hline 36 & Distractibility & Never or rarely & $\begin{array}{c}\text { Some of the } \\
\text { time }\end{array}$ & Most of the time \\
\hline 37 & Negative Affect & Never or rarely & $\begin{array}{c}\text { Some of the } \\
\text { time }\end{array}$ & Most of the time \\
\hline
\end{tabular}

\section{Additional information:}


Int. J. Growth Dev. 2018, 2: 11-33

http://igdjournal.com/

\section{S6 Note on Covariate Analysis}

Covariate analysis, for group assessments, revealed (i) no significant association with sex (ii) significant differences in cognition scores between the preschools Yoltzin and Mundo de Andi ( $\mathrm{F}=3.45, \mathrm{p}=0.03)$ and in expressive language scores between Casita de Susi, Mundo de Andi and CBI $(F=4.16, p=0.01)$ (iii) Significant associations between expressive language and receptive language scores, and age and head circumference of the child at the time of assessment (For Age: $r=0.46$, $\mathrm{p}<0.001, \mathrm{r}=0.34, \mathrm{p}=0.04$ respectively; For Head Circumference: $\mathrm{r}=0.44, \mathrm{p}<0.001, \mathrm{r}=0.38, \mathrm{p}=0.02$ ). No significant associations were found between INTER-NDA domain scores and weight or length of the child at the time of the assessment. Covariate analysis, for individual assessments, revealed (i) no significant association with sex ( $\mathrm{t}=-0.75$ to $1.52, \mathrm{p}=0.14$ to 0.93 ) (ii) significant differences in cognition scores between the preschools Yoltzin and Mundo de Andi ( $F=3.21$, $p=0.02)$ (iii) Significant associations between expressive language and age of the child $(\mathrm{r}=-0.54, \mathrm{p}<0.001)$. No significant associations were found between INTER-NDA domain scores and weight, length or head circumference. Based on the analysis above, location of preschool, age of the child and anthropometry were included as covariates in the regression analysis. Although no association with sex was found in our study, sex was included as a covariate in the analysis based on evidence from previous literature that neurodevelopment scores differ between boys and girls. 